\title{
A Systematic Evaluation Model for Solar Cell Technologies
}

\author{
Chang-Fu Hsu, ${ }^{1}$ Rong-Kwei Li, ${ }^{1}$ He-Yau Kang, ${ }^{2}$ and Amy H. I. Lee ${ }^{3}$ \\ ${ }^{1}$ Department of Industrial Engineering and Management, National Chiao-Tung University, Hsinchu 300, Taiwan \\ ${ }^{2}$ Department of Industrial Engineering and Management, National Chin-Yi University of Technology, Taichung 411, Taiwan \\ ${ }^{3}$ Department of Technology Management, Chung Hua University, No. 707, Sector 2, WuFu Road, Hsinchu 300, Taiwan
}

Correspondence should be addressed to Amy H. I. Lee; amylee@chu.edu.tw

Received 4 October 2013; Revised 12 February 2014; Accepted 13 February 2014; Published 17 April 2014

Academic Editor: Ching-Ter Chang

Copyright (C) 2014 Chang-Fu Hsu et al. This is an open access article distributed under the Creative Commons Attribution License, which permits unrestricted use, distribution, and reproduction in any medium, provided the original work is properly cited.

\begin{abstract}
Fossil fuels, including coal, petroleum, natural gas, and nuclear energy, are the primary electricity sources currently. However, with depletion of fossil fuels, global warming, nuclear crisis, and increasing environmental consciousness, the demand for renewable energy resources has skyrocketed. Solar energy is one of the most popular renewable energy resources for meeting global energy demands. Even though there are abundant studies on various solar technology developments, there is a lack of studies on solar technology evaluation and selection. Therefore, this research develops a model using interpretive structural modeling (ISM), benefits, opportunities, costs, and risks concept (BOCR), and fuzzy analytic network process (FANP) to aggregate experts' opinions in evaluating current available solar cell technology. A case study in a photovoltaics (PV) firm is used to examine the practicality of the proposed model in selecting the most suitable technology for the firm in manufacturing new products.
\end{abstract}

\section{Introduction}

Energy is an essential element for civilization development of mankind and quality improvement of life. The use of fossil fuels and other natural resources has resulted in detrimental impacts on the environment, especially through the damage to the air, climate, water, land, and wildlife [1]. With increase in both environmental awareness and global demand for energy, the utilization of clean energy sources is necessary. Although global economic recession has slowed the demand for energy currently, renewable resources energy is still necessary for the green environment and for the economic growth in the long term. Solar energy, one of the promising and clean renewable energy sources, is becoming a favorable option of renewable energy source [2].

Photovoltaic (PV) solar cells are semiconductor devices that transfer solar radiation into electricity by converting the energy of the sunlight to direct current electricity after photovoltaic effect [3]. The solar panels that consisted of several solar cells made up of photovoltaic material are the key device to generate the photovoltaic power. Due to the strong need for renewable energy of solar cells, solar photovoltaics is now the third most promising renewable energy source to provide cleaner and abundant energy after hydro- and wind power [4]. However, the major issue of solar cells encountered is still the high energy cost compared to conventional energy sources [5]. With the improvement in technology and increase in manufacturing scale, the cost of photovoltaics solar cells has reduced continuously since the first cells were produced [6]. The manufacturing of PV solar cells typically involves similar but simpler methods to those applied in chip fabrication. PV solar cells can be categorized into two major types: wafer-based silicon and thin film. Currently, cell materials applied to photovoltaic solar cells include crystalline silicon, III-V cells, thin film chalcogenide, amorphous/nanocrystalline silicon, and organic thin film or module, with different conversion efficiencies and manufacturing technology [7].

Regardless of the effort in making proper cost-benefit solar cells by using new materials and new technologies, the predominant wafer-based silicon technology, or so-called first-generation solar cell [8], is still expected to maintain its market share at levels of around $80 \%$ [4]. A lot of research continues in the field of silicon wafer-based solar cell to achieve the goal of lower cost and higher conversion efficiencies for obtaining the most possible electricity from the least amount of silicon [9]. There are two types of the crystalline solar cells: single crystalline silicon solar cells 
and polycrystalline silicon solar cells. The first one uses monocrystal substrates from pure homogenous silicon with the highest efficiency (up to 24\%) [10]. The process of single crystalline is much like those applied to fabricate semiconductor chips; however, they are the most expensive to manufacture because of the need of a crystalline ingot of pure silicon [9]. Polycrystalline (also called multicrystalline) silicon wafers, which are a material consisting of multiple small silicon crystals, are made by melting and then solidifying silicon. The modules are made from an array of silicon wafers that have been connected together. With the characteristic of large areas manufacturing, polycrystalline solar cells currently have the largest share of the market, with equivalent module efficiency and lower fabricating costs than the monocrystalline type.

With the huge growth expectations of thin film solar cell technologies, the competing market price of crystallinesilicon has slowed the development of thin film solar cell. The latter is expected to grow anyway at a lower rate because of its potential reduction of production costs, low material consumption, lower energy consumption, and a shorter energy payback time [11]. Therefore the thin film solar cells will stabilize their market share over the next five years [4]. The silicon wafers used to make crystalline silicon solar cells are costly, composed of $20-40 \%$ of the final module cost [12]. In opposite, thin film solar cells require only a few microns of thickness of silicon on substrate compared to hundreds of microns of thickness for a wafer-based cell [8]. Nevertheless, there are some aspects that need to be improved for the thin film solar cells technology such as better solar radiation conversion efficiency, more product stability for different absorption rates of lights with different wavelengths, and lower deterioration capability after extensive sun exposure for longer product lifetime [13]. There is also a third-generation solar cell technology, which attempts to improve the conversion efficiencies light radiation of thin film technologies to $30-60 \%$ while maintaining low production costs [8]. Some approaches include multijunction photovoltaic cell (multiple energy threshold devices), modifying incident spectrum (concentration), using excess thermal generation (by UV light), and using infrared spectrum [8].

Advanced production technologies can help reduce production cost, improve product quality, and increase yield rate, and these technologies can be related to process engineering, system integration, production automation, and process equipment [13]. Furthermore, the introduction of new materials (such as nano- and microcrystalline silicon thin film solar cell), advanced devices (such as laser scriber), and new methods (such as extremely thin absorber) can also enhance solar conversion efficiency, decrease production costs, and extend product lifetime $[3,14]$. The demand of raw materials increases substantially [13]. For example, glass substrate and silane, the material for making crystalline silicon, are essential materials for making thin film solar cells and modules [14].

Even though there are abundant studies on the development of various solar technologies, there are very few studies on solar technology evaluation and selection. To survive in the global competition, firms need continuously to develop new products these days. Before a new technology is introduced, a firm needs to consider and evaluate available technologies first and then select the most suitable one in an efficient way. It is a multidisciplinary process to make the decision in choosing the most appropriate technology to fabricate products since this process needs to integrate different professional knowledge, production management, and market trend. Therefore, the decision should not only consider the expected benefits a technology can bring in making the final products with specified quality, but also cover other aspects, such as opportunities, costs, and risks. As a result, the technology selection is a sophisticated evaluation process which must consider multiple attributes.

Technology selection is not a new research topic; however, very little research has examined the interrelationship of the criteria in the decision making process and considered the positive and negative aspects of the alternatives simultaneously. Thus, this paper, based on the model proposed by Lee et al. [15], constructed a refined model. The model applies interpretive structural modeling (ISM) to take into account the interrelationship of the criteria and adopts benefits, opportunities, costs, and risks (BOCR) merits to consider the various aspects of the alternatives. Fuzzy set theory is applied to the analytic network process (ANP) model, or so-called FANP, for the selection of solar cell technologies. By applying the fuzzy set theory, the model can consider the uncertainty and fuzziness of experts' opinions. As a result, a more credible decision can be made. In addition, the model can help experts understand the problem comprehensively, so that different aspects can be examined in evaluating various solar cell technologies. The remaining part of this paper is organized as follows. Section 2 studies some recent technology evaluation models. Section 3 reviews the works of the solar industry in Taiwan. Section 4 develops a systematic model for evaluating solar cell technologies. In Section 5, the model is applied to a solar cell manufacturer in Taiwan for technology selection. The last section contains the conclusions.

\section{Review of Technology Evaluation Models}

Many approaches on technology evaluation have been presented in previous studies. Internal rate of return (IRR), net present value (NPV), return on investment (ROI), and payback period $(\mathrm{PB})$ have been traditionally applied to evaluate technology alternatives from financial viewpoint [16]. Three basic types for evaluating a technology's economic value are cost approach, market approach, and income approach [17]. Other than the financial value of technologies, elements, such as product quality, time to completion, flexibility, price, legal protection, scope of application, and capacity expansion, are often considered $[17,18]$.

Technology evaluation problem is a multicriteria decision making (MCDM) problem, and it should involve the opinions of multiple experts and consider fuzzy assessments [15]. Some of recent works are reviewed as follows. Hung and Tseng [17] considered four major factors, technology market factor, legal protection factor, product market factor, and cost dimension factor, and proposed a technology evaluation framework. Hsu et al. [19] acquired the critical factors of 
regenerative technologies by adopting fuzzy Delphi method and calculated the importance of each evaluation criterion using fuzzy analytic hierarchy process (FAHP). Lee et al. [15] presented an integrated model for evaluating various technologies for new product development for flat panel manufacturing. The model adopted benefits, opportunities, costs, and risks (BOCR), ISM, and FANP to facilitate the evaluation process. Kang et al. [20] proposed a model that adopted ISM and FANP to assess different available technologies for a flat panel manufacturer. Alamian et al. [21] aimed to evaluate technologies for harvesting wave energy in the Caspian Sea. The most important design parameters for wave energy converter devices were identified first, and the major features, including power production, sea conditions, device installation, and electrical system, were listed in a benchmark table. With assigned weighting for each factor, the synthesized scores for each technology were obtained. Bassano et al. [22] performed a modeling and economic evaluation of the integration of carbon capture and storage technologies into coal-to-liquid plants. The system configuration and plant performance were evaluated first using Aspen Plus software, and the economic analysis, including the IRR, PB, and NPV, was performed next.

To summarize, even though technology evaluation is a MCDM problem in nature, relatively few models have been proposed. This study applies and revises the model proposed by Lee et al. [15] and constructs a model for evaluating solar cell technologies that should be used in solar cell production. While triangular fuzzy numbers are adopted in Lee et al. [15], both triangular and trapezoidal fuzzy numbers are adopted in this work. In addition, $\alpha$-cuts integral approach is applied to defuzzification here, instead of the center of gravity method, which is applied in Lee et al. [15].

\section{Studies of the Solar Industry in Taiwan}

The solar industry in Taiwan has a great potential in the global market due to the technical advantages gained from the semiconductor industry and the TFT-LCD industry [20]. In the past few years, many PV firms have been developed in the market. Some studies on the solar industry in Taiwan are briefly reviewed here. Lee [23] constructed an industrial portfolio analysis model to evaluate the industrial innovation requirements and national policies that were necessary for the development of Taiwan's solar cell industry. Data collection included literature analysis, expert interview, and general survey, and the relationship between market growth curve and industrial production chain was analyzed. Lai [24] studied the localized core competencies of the PV industry in Taiwan through literature reviews and interviews with experts in the industry and used Michael Porter's diamond model, Andrew Grove's six forces analysis, value chain analysis, and SWOT analysis to analyze these competencies. Several competitive strategies were then proposed to help establish a unique position in the global PV industry for Taiwan. Yue and Wang [25] established an evaluation model for developing renewable energy sources, including wind, solar, and biomass energy sources, in Chigu area of southwestern Taiwan by analyzing technical, economic, environmental, and political implications. A GIS is used to assess the local conditions, and factors such as climate conditions, land uses, and ecological environments are considered. Chen et al. [26] studied the development of various renewable energies in Taiwan, reviewed the promotional and subsidy programs implemented by the Taiwanese government, and proposed future plans achievements. Ting [27] reviewed the development of solar cell technology, status of global industry, and strategy of major companies and discussed the dynamics and trend of the industry. The study described the performance and strategy of the leader companies in Taiwan and discussed the competitive advantage and positioning of the companies. Chen [28] studied historical data to understand the development and current situation of global and Taiwan's thin film PV industry. The competitiveness of the industries in different countries was analyzed, and a recommendation was proposed to increase the competitive advantages of the industry in Taiwan. Welling [29] analyzed Taiwan's solar cell process equipment industry based on an innovative intensive service analysis model by structuring a 4 by 5 matrix, encompassing four customization levels and five innovation levels, in order to study the strategic position and future development trend of the industry. Hwang [30] also reviewed promotional policy of renewable energy in Taiwan. The growth opportunities of individual renewable energies by considering the technology development, domestic conditions, and indigenous industries related to renewable energy were suggested. Lee et al. [31] studied the current business performance of PV firms in Taiwan and proposed a performance evaluation model by integrating analytic hierarchy process (AHP) and data envelopment analysis (DEA). Lee et al. [32] proposed a two-stage performance evaluation framework for PV firms. In the first stage, assurance regions (AR) of the factors were set by the FAHP and the business performance of the firms was evaluated by the DEA. In the second stage, the changes in efficiency of each firm over time were assessed by the Malmquist productivity index (MPI).

\section{A Systematic Model for Evaluating Solar Cell Technologies}

A model, based on the model proposed by Saaty [33], Saaty [34], Lee et al. [15], and Kang et al. [35], is constructed here to help evaluate suitable solar cell technologies in a firm. The model incorporates ISM, FANP, and BOCR and contains three phases: the construction of control hierarchy and BOCR-ANP network, the calculation of priority weights, and the ranking of technology alternatives. The steps are as follows.

Step 1. Form a committee of experts in a solar firm to define the solar cell technology evaluation problem.

Phase I: The Construction of Control Hierarchy and BOCRANP Network

Step 2. Develop a control hierarchy for the solar cell technology evaluation problem. The control hierarchy has 


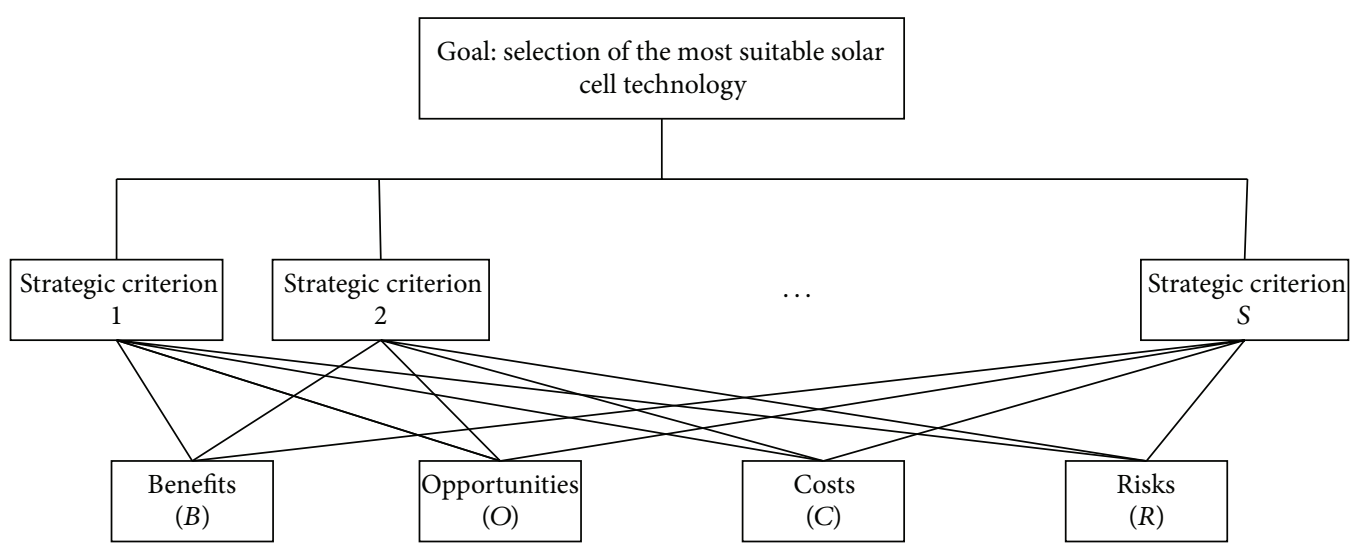

FIgURE 1: The control hierarchy for solar cell technology selection.

several strategic criteria and four merits, benefits $(B)$, opportunities $(O)$, costs $(C)$, and risks $(R)$, as shown in Figure 1. The goal of the control hierarchy is to determine the importance of the four merits, which are $b, o, c$, and $r$, respectively.

Step 3. Develop a network with BOCR subnetworks. Based on literature review and interview with the experts, the problem can be decomposed into a network, as depicted in Figure 2. To attain the goal of selecting the most appropriate solar cell technology, we need to consider four merits $(B, O, C$, and $R$ ). Thus, a subnetwork is formed for each merit. For instance, the benefits $(B)$ subnetwork contains some criteria that need to achieve the benefits aspect, and these criteria may be interrelated. In addition, technology alternatives are in the lowest level for evaluation.

Step 4. Develop a relation matrix for the criteria under each merit. Experts are asked to identify whether there is a relation between any two criteria and what the direction of the relation is. Then, a relation matrix $\mathbf{D}_{M}$ is built to show the contextual relationship among the criteria for merit $M$. Consider

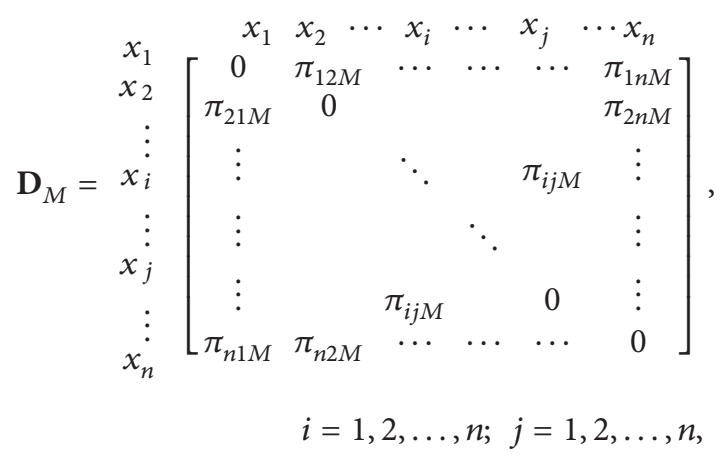

where $\pi_{i j M}$ is the relation between criteria $x_{i}$ and $x_{j}$. If $x_{j}$ is reachable from $x_{i}, \pi_{i j M}=1$; otherwise, $\pi_{i j M}=0$.

Step 5. Construct an initial reachability matrix for each merit. By adding $\mathbf{D}_{M}$ with the unit matrix $\mathbf{I}$, the initial reachability matrix $\mathbf{R}_{M}$ is calculated:

$$
\mathbf{R}_{M}=\mathbf{D}_{M}+\mathbf{I} .
$$

Step 6. Calculate the final reachability matrix $\mathbf{R}_{M}^{*}$ for each merit. Convergence of the relationship can be met using the operators of the Boolean multiplication and addition. That is, $0 \times 0=0,1 \times 0=0 \times 1=0,1 \times 1=1,0+0=0,1+0=$ $0+1=1$, and $1+1=1$. The final reachability matrix $\mathbf{R}_{M}^{*}$ is

$$
\begin{aligned}
& \mathbf{R}_{M}^{*}=\mathbf{R}_{M}^{b}=\mathbf{R}_{M}^{b+1}, \quad b>1 \\
& \begin{array}{llllllll}
x_{1} & x_{2} & \cdots & x_{i} & \cdots & x_{j} & \cdots & x_{n}
\end{array}
\end{aligned}
$$

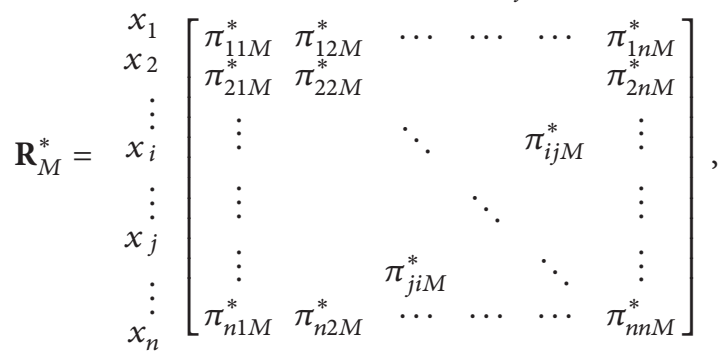

$$
\begin{aligned}
& i=1,2, \ldots, n ; j=1,2, \ldots, n,
\end{aligned}
$$

where $\pi_{i j M}^{*}$ is the impact of criterion $x_{i}$ to criterion $x_{j}$ under merit $M$.

Step 7. Develop a subnetwork for the criteria under each merit based on $\mathbf{R}_{M}^{*}$ for the merit.

\section{Phase II: The Calculation of Priority Weights}

Step 8. Prepare a questionnaire based on Figures 1 and 2 and the subnetworks developed in Step 7. Based on Figure 1, the questionnaire contains the pairwise comparison of the importance of the strategic criteria and the rating of the importance of each merit $(B, O, C$, and $R)$ with respect to each strategic criterion. Based on Figure 2 and the subnetworks developed in Step 7, the questionnaire contains the pairwise comparison of the importance of the criteria under each merit, the pairwise comparison of the interdependence 


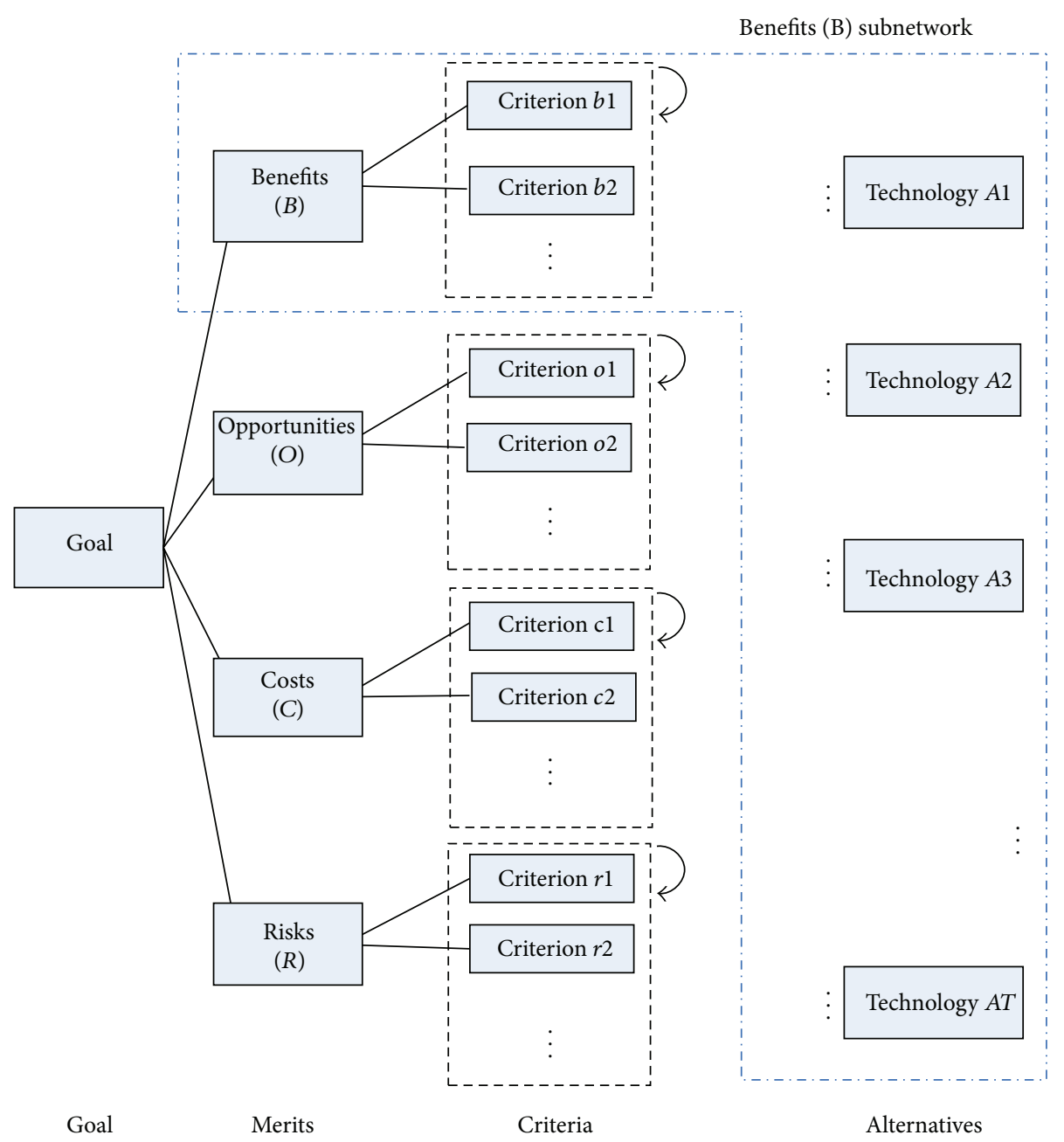

FIGURE 2: The BOCR-ANP network for solar cell technology selection.

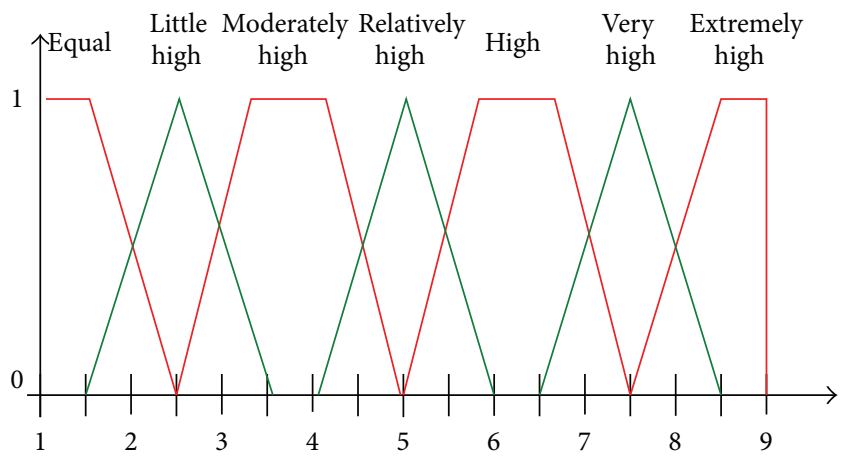

FIGURE 3: Fuzzy numbers for relative importance/performance.

among the criteria under each merit, and the pairwise comparison of the expected performance of the technologies under each criterion. The experts in the firm are asked to fill out the questionnaire.

Step 9. Based on the control hierarchy, two kinds of information are collected through the questionnaire. First, experts

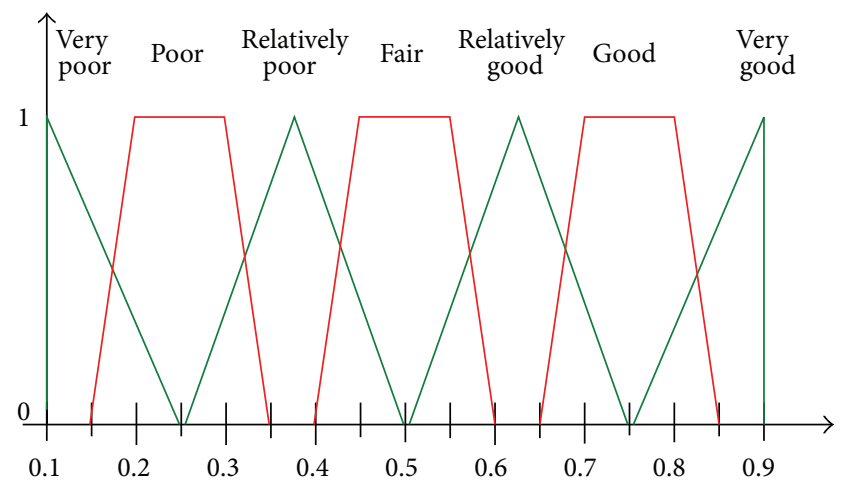

FIgURE 4: Fuzzy numbers for ranking.

are asked to pairwise compare the importance of the strategic criteria with seven linguistic terms, as shown in Figure 3. Using Figure 3, the linguistic variables are transformed into trapezoid fuzzy numbers. Second, the importance of each 


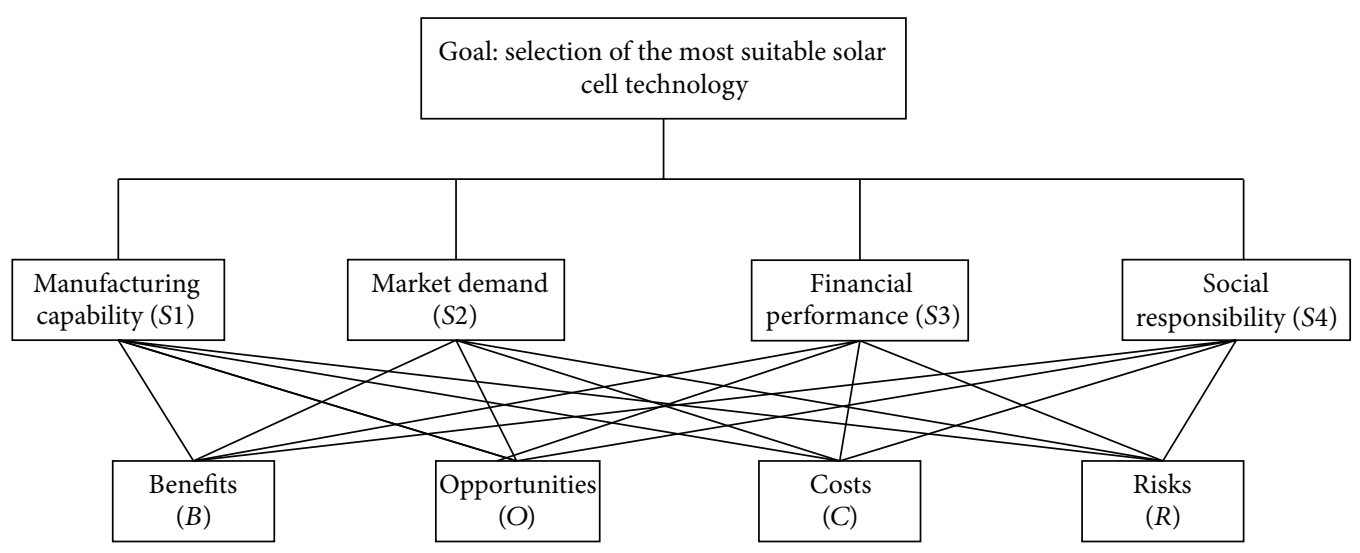

FIGURE 5: The control hierarchy for solar cell technology selection.

merit $(B, O, C$, and $R)$ on each strategic criterion is determined by the experts also using a seven-step scale, as shown in Figure 4.

Step 10. Calculate the importance of the strategic criteria. Aggregate experts' responses by employing geometric average approach, and a synthetic trapezoid fuzzy number is calculated as follows:

$$
\tilde{r}_{i j}=\left(\tilde{a}_{i j 1} \otimes \tilde{a}_{i j 2} \otimes \cdots \otimes \tilde{a}_{i j k}\right)^{1 / k},
$$

where $\widetilde{a}_{i j k}$ is the pairwise comparison value between strategic criteria $i$ and $j$ determined by expert $k$.

Defuzzify fuzzy number $\widetilde{\gamma}_{i j}$ into a crisp number $\gamma_{i j}$ using Yager [36] ranking method, and the $\alpha$-cuts of the fuzzy numbers are listed in Table 1:

$$
\gamma_{i j}=\int_{0}^{1} \frac{1}{2}\left(\left(\tilde{\gamma}_{i j}\right)_{\alpha}^{L}+\left(\tilde{\gamma}_{i j}\right)_{\alpha}^{U}\right) \mathrm{d} \alpha
$$

After defuzzification, the aggregated pairwise comparison matrix is

$$
\mathbf{W}_{S}=\left[\begin{array}{ccccccc}
1 & \gamma_{12} & \cdots & \cdots & \cdots & \cdots & \gamma_{1 j} \\
\frac{1}{\gamma_{12}} & 1 & \cdots & \cdots & \cdots & \cdots & \gamma_{2 j} \\
\vdots & \vdots & 1 & \cdots & \cdots & \cdots & \cdots \\
\vdots & \vdots & \vdots & 1 & \gamma_{i j} & \cdots & \cdots \\
\vdots & \vdots & \vdots & \frac{1}{\gamma_{i j}} & 1 & \cdots & \cdots \\
\cdots & \cdots & \cdots & \cdots & \cdots & 1 & \cdots \\
\frac{1}{\gamma_{1 j}} & \frac{1}{\gamma_{2 j}} & \cdots & \cdots & \cdots & \cdots & 1
\end{array}\right] .
$$

Priority vector for the aggregated comparison matrix is derived:

$$
\mathbf{W}_{S} \times w_{s}=\lambda_{\max } \times w_{s}
$$

where $\mathbf{W}_{S}$ is the aggregated comparison matrix, $w_{s}$ is the eigenvector, and $\lambda_{\max }$ is the largest eigenvalue of $\mathbf{W}_{S}$.
Step 11. Check the consistency of the aggregated comparison matrix. The consistency index (CI) and consistency ratio $(\mathrm{CR})$ are $[33,37]$

$$
\begin{gathered}
\mathrm{CI}=\frac{\lambda_{\max }-n}{n-1}, \\
\mathrm{CR}=\frac{\mathrm{CI}}{\mathrm{RI}},
\end{gathered}
$$

where $n$ is the number of items being compared in the matrix and RI is random index [37].

The experts are asked to revise the part of the questionnaire if there is an inconsistency, and the calculations in Step 10 are done again. Once the consistency test is passed, the priorities of the strategic criteria are determined.

Step 12. Calculate the importance of each merit $(B, O, C$, and $R$ ) with respect to each strategic criterion. Based on the information collected in Step 9, aggregate experts' responses using the geometric average approach. Yager ranking method [36] is used to defuzzify each fuzzy number into a crisp number.

Step 13. Calculate the priorities of the merits. The priority of a merit is obtained by multiplying the importance of the merit on each strategic criterion from Step 12 with the priority of the respective strategic criterion from Step 11 and summing up the calculated values for the merit. The priorities of benefits, opportunities, costs, and risks, that is, $b, o, c$, and $r$, are calculated by normalizing the calculated values of the four merits.

Step 14. Calculate the relevant priorities on the BOCR-ANP network in Figure 2 and the subnetworks developed in Step 7. A similar procedure as in Steps 10 and 11 is adopted to calculate the relative importance weights of the criteria with respect to the same upper-level merit, the interdependence of the criteria with respect to the same upper-level merit, and 
TABLE 1: $\alpha$-Cuts of fuzzy numbers.

\begin{tabular}{|c|c|c|}
\hline$\tilde{a}$ & $(\widetilde{a})_{\alpha}^{L}$ & $(\widetilde{a})_{\alpha}^{U}$ \\
\hline$\tilde{a}_{V H}=(7.5,8.5,9,9)_{\mathrm{L}-\mathrm{R}}$ & $\left(\tilde{a}_{V H}\right)_{\alpha}^{L}=7.5+\alpha$ & $\left(\widetilde{a}_{V H}\right)_{\alpha}^{U}=9$ \\
\hline$\tilde{a}_{H}=(6.5,7.5,7.5,8.5)_{\mathrm{L}-\mathrm{R}}$ & $\left(\widetilde{a}_{H}\right)_{\alpha}^{L}=6.5+\alpha$ & $\left(\widetilde{a}_{H}\right)_{\alpha}^{U}=8.5-\alpha$ \\
\hline$\tilde{a}_{M H}=(5,5.75,6.75,7.5)_{\mathrm{L}-\mathrm{R}}$ & $\left(\tilde{a}_{M H}\right)_{\alpha}^{L}=5+0.75 \alpha$ & $\left(\tilde{a}_{M H}\right)_{\alpha}^{U}=7.5-0.75 \alpha$ \\
\hline$\tilde{a}_{M}=(4,5,5,6)_{\mathrm{L}-\mathrm{R}}$ & $\left(\tilde{a}_{M}\right)_{\alpha}^{L}=4+\alpha$ & $\left(\tilde{a}_{M}\right)_{\alpha}^{U}=6-\alpha$ \\
\hline$\tilde{a}_{M L}=(2.5,3.25,4.25,5)_{\mathrm{L}-\mathrm{R}}$ & $\left(\widetilde{a}_{M L}\right)_{\alpha}^{L}=2.5+0.75 \alpha$ & $\left(\widetilde{a}_{M L}\right)_{\alpha}^{U}=5-0.75 \alpha$ \\
\hline$\tilde{a}_{L}=(1.5,2.5,2.5,3.5)_{\mathrm{L}-\mathrm{R}}$ & $\left(\tilde{a}_{L}\right)_{\alpha}^{L}=1.5+\alpha$ & $\left(\tilde{a}_{L}\right)_{\alpha}^{U}=3.5-\alpha$ \\
\hline$\tilde{a}_{V L}=(1,1,1.5,2.5)_{\mathrm{L}-\mathrm{R}}$ & $\left(\tilde{a}_{V L}\right)_{\alpha}^{L}=1$ & $\left(\tilde{a}_{V L}\right)_{\alpha}^{U}=2.5-\alpha$ \\
\hline
\end{tabular}

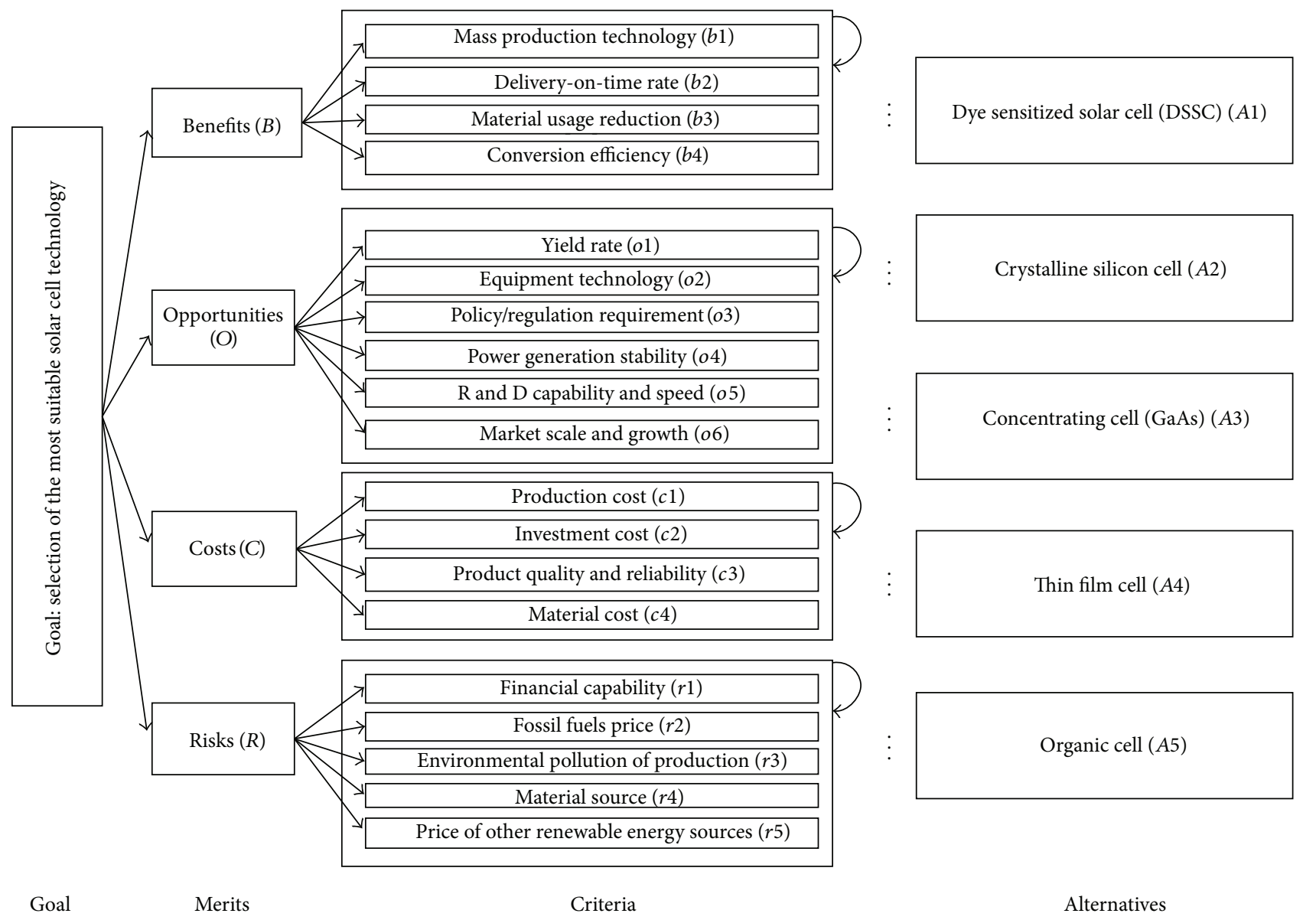

FIGURE 6: The BOCR-ANP network for solar cell technology selection.

the expected relative performance of technologies with respect to each criterion.

\section{Phase III: The Ranking of Technology Alternatives}

Step 15. Prepare an unweighted supermatrix for each merit using the priorities obtained from Step 14, as depicted in the following matrix, where $w_{c m}^{M}$ is a vector that shows the impact of merit $M$ on the criteria, $\mathbf{W}_{c c}^{M}$ represents the interdependency of the criteria, $\mathbf{W}_{a c}^{M}$ is a matrix that indicates the impact of criteria on each alternative, and $\mathbf{I}$ is the identity matrix.
Unweighted supermatrix for merit $M[15]$ is

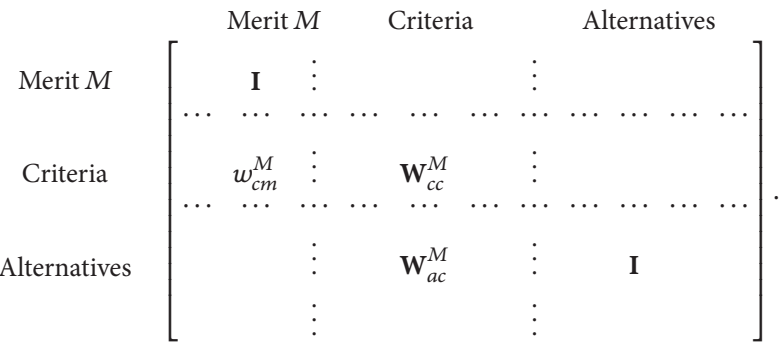




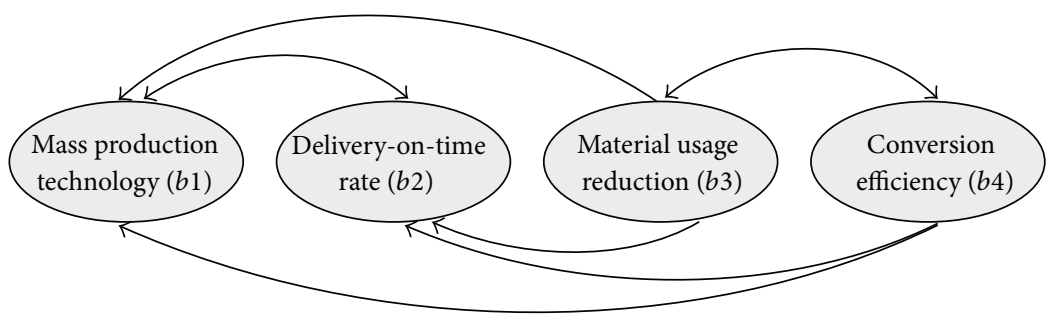

FIGURE 7: Subnetwork for the criteria under the benefits merit.

Step 16. Obtain the weighted supermatrix for each merit subnetwork. One approach is to determine the relative importance of the clusters in the supermatrix with the column cluster (block) as the controlling component [33]. Another popular approach is to assign equal weights to the blocks in the same column and to make each column sum to unity [38].

Step 17. Obtain the priorities of technology alternatives under each merit subnetwork. Calculate the limit supermatrix for each merit subnetwork by raising the weighted supermatrix to powers. The priorities of the technology alternatives under each merit are found in the alternative-to-goal column of the limit supermatrix of the merit.

Step 18. Obtain overall priorities of the technology alternatives by synthesizing the priorities of each alternative under each merit from Step 17 with the corresponding normalized weights $b, o, c$, and $r$ from Step 13. Five popular ways can be used to calculate the overall priority of each alternative [34].

Additive. Consider

$$
P_{t}=b B_{t}+o O_{t}+c\left(\frac{1}{C_{t}}\right)_{\text {Normalized }}+r\left(\frac{1}{R_{t}}\right)_{\text {Normalized }},
$$

where $B_{t}, O_{t}, C_{t}$, and $R_{t}$ represent the synthesized results of alternative $t$ under merits $B, O, C$, and $R$, respectively, and $b, o, c$, and $r$ are normalized weights of merits $B, O, C$, and $R$, respectively.

Probabilistic Additive. Consider

$$
P_{t}=b B_{t}+o O_{t}+c\left(1-C_{t}\right)+r\left(1-R_{t}\right) .
$$

Subtractive. Consider

$$
P_{t}=b B_{t}+o O_{t}-c C_{t}-r R_{t} .
$$

Multiplicative Priority Powers. Consider

$$
P_{t}=B_{t}^{b} O_{t}^{o}\left[\left(\frac{1}{C_{t}}\right)_{\text {Normalized }}\right]^{c}\left[\left(\frac{1}{R_{t}}\right)_{\text {Normalized }}\right]^{r} .
$$

Multiplicative. Consider

$$
P_{t}=\frac{B_{t} O_{t}}{C_{t} R_{t}}
$$

Step 19. Perform sensitivity analysis to examine the robustness of the outcomes. By changing the priorities of the merits, Steps 15-18 are performed again to check whether the ranking of alternatives changes and at what priority the ranking changes.

\section{Case Study}

The proposed model is applied to an anonymous solar cell manufacturer in Taiwan to select the most suitable solar cell technology. A comprehensive literature review is done first, and some experts in the solar cell technology field are interviewed. A control hierarchy and an ANP-BOCR network are developed by the authors and verified by the experts, as shown in Figures 5 and 6, respectively. Four strategic criteria are named: manufacturing capability, market demand, financial performance, and social responsibility. The four merits are benefits $(B)$, opportunities $(O)$, costs $(C)$, and risks $(R)$, under each of which there are a number of criteria. For instance, the benefits that may be acquired from adopting a solar cell technology include mass production technology (b1), delivery-on-time rate (b2), material usage reduction (b3), and conversion efficiency (b4). The most probable technologies in making solar cells are dye sensitized solar cell (DSSC) $(A 1)$, crystalline silicon cell $(A 2)$, concentrating cell (GaAs) (A3), thin film cell (A4), and organic cell (A5).

The interrelationship among the criteria under the same upper-level merit is determined through the ISM. Experts' consensus is obtained through the Delphi method, and a relation matrix under each merit is prepared. The relation matrix among the criteria under benefits, $D_{B}$, is

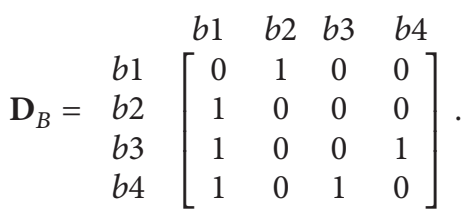

Using Step 5, we can obtain the initial reachability matrix $\mathbf{R}_{B}$ for the criteria under benefits:

$$
\begin{aligned}
\mathbf{R}_{B}=\mathbf{D}_{B}+\mathbf{I} & =\left[\begin{array}{llll}
0 & 1 & 0 & 0 \\
1 & 0 & 0 & 0 \\
1 & 0 & 0 & 1 \\
1 & 0 & 1 & 0
\end{array}\right] \\
& +\left[\begin{array}{llll}
1 & 0 & 0 & 0 \\
0 & 1 & 0 & 0 \\
0 & 0 & 1 & 0 \\
0 & 0 & 0 & 1
\end{array}\right]=\left[\begin{array}{llll}
1 & 1 & 0 & 0 \\
1 & 1 & 0 & 0 \\
1 & 0 & 1 & 1 \\
1 & 0 & 1 & 1
\end{array}\right] .
\end{aligned}
$$


After the calculation, the final reachability matrix $\mathbf{R}_{B}^{*}$ for the criteria under benefitsis

$$
\mathbf{R}_{B}^{*}=\mathbf{R}_{B}^{2}=\left[\begin{array}{llll}
1 & 1 & 0 & 0 \\
1 & 1 & 0 & 0 \\
1 & 1 & 1 & 1 \\
1 & 1 & 1 & 1
\end{array}\right]
$$

Based on $\mathbf{R}_{B}^{*}$, we can determine the interrelationship among the four criteria under benefits, as shown in Figure 7. The direction of an arrow shows the dependence, and a twoway arrow means that the two criteria are interdependent. Using the same procedure, the interrelationships among the criteria under the other three merits are determined, as shown in Figures 8, 9, and 10, respectively.

Based on the network in Figure 6 and the interrelationship among the criteria under the four merits in Figure 7 to Figure 10, a questionnaire is prepared. Nine experts, including one project manager, one engineering manager, one production manager, two senior $\mathrm{R}$ and $\mathrm{D}$ engineers, two quality managers, and two marketing managers, in the firm are asked to fill out the questionnaire. For example, the four strategic criteria are pairwise compared using seven different

linguistic terms shown in Figure 3. An aggregated pairwise comparison matrix is prepared next to synthesize experts' opinions. For example, the pairwise comparisons between manufacturing capability (S1) and market demand (S2) by the experts are "little high," "equal," "equal," "little high," "equal," "little high," "equal," "little high," and "little high." The fuzzy numbers are $(1.5,2.5,2.5,3.5),(1,1,1.5,2.5),(1,1,1.5$, $2.5),(1.5,2.5,2.5,3.5),(1,1,1.5,2.5),(1.5,2.5,2.5,3.5),(1,1,1.5$, $2.5),(1.5,2.5,2.5,3.5)$, and $(1.5,2.5,2.5,3.5)$. By applying (4), the aggregated trapezoid fuzzy number is

$$
\begin{aligned}
(1.25,1.66,1.99,3.01) & \\
= & \left((1.5 \times 1 \times 1 \times 1.5 \times 1 \times 1.5 \times 1 \times 1.5 \times 1.5)^{1 / 9},\right. \\
& (2.5 \times 1 \times 1 \times 2.5 \times 1 \times 2.5 \times 1 \times 2.5 \times 2.5)^{1 / 9}, \\
& (2.5 \times 1.5 \times 1.5 \times 2.5 \times 1.5 \times 2.5 \times 1.5 \times 2.5 \times 2.5)^{1 / 9} \\
& (3.5 \times 2.5 \times 2.5 \times 3.5 \times 2.5 \\
& \left.\times 3.5 \times 2.5 \times 3.5 \times 3.5)^{1 / 9}\right) .
\end{aligned}
$$

The fuzzy aggregated pairwise comparison matrix for the strategic criteria is

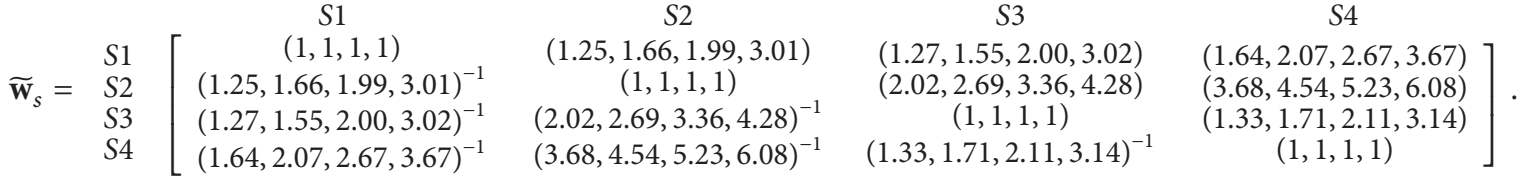

A defuzzified comparison matrix is prepared by the Yager [36] ranking method using (5). For example, the synthetic trapezoid fuzzy number for the comparison between $S 1$ and $S 2$ is $1.25,1.66,1.99$, and 3.01. The defuzzified comparison between $S 1$ and $S 2$ is 1.98 . Thus, the defuzzified aggregated pairwise comparison matrix is

$$
\mathbf{W}_{s}=\begin{gathered}
S 1 \\
S 2 \\
S 3 \\
S 4
\end{gathered}\left[\begin{array}{cccc}
S 1 & S 2 & S 3 & S 4 \\
1 & 1.981 & 1.958 & 2.512 \\
0.505 & 1 & 3.087 & 4.885 \\
0.511 & 0.324 & 1 & 2.072 \\
0.398 & 0.205 & 0.483 & 1
\end{array}\right] .
$$

Then, the priority vector, that is, $w_{s}$, and $\lambda_{\max }$ of $\mathbf{W}_{S}$ are calculated using (7):

$$
w_{s}=\begin{array}{ll}
S 1 \\
S 2 \\
S 3
\end{array}\left[\begin{array}{l}
0.381 \\
0.358 \\
0.165 \\
\text { S }
\end{array}\right], \quad \lambda_{\max }=4.218
$$

By applying Step 11, we can check the consistency of the defuzzified aggregated pairwise comparison matrix. Consider

$$
\begin{gathered}
\mathrm{CI}=\frac{\lambda_{\max }-n}{n-1}=\frac{4.218-4}{4-1}=0.073 \\
\mathrm{CR}=\frac{\mathrm{CI}}{\mathrm{RI}}=\frac{0.073}{0.9}=0.081 .
\end{gathered}
$$

Because CR is less than 0.1, the consistency test is passed. In the opinions of the experts, manufacturing capability $(S 1)$ is the most important strategic criterion with a priority of 0.381 , followed by market demand $(S 2)$ with a priority of 0.358 .

Next, the importance of each merit to each strategic criterion is determined. A seven-level linguistic scale is used to collect the experts' opinions in the questionnaire, and each linguistic scale is assigned a trapezoid fuzzy number. The outcomes from the experts are aggregated using the geometric average method, and the fuzzy numbers are defuzzified by the Yager [36] ranking method. Table 2 shows the integrated fuzzy weights of the four merits on strategic criteria. The overall priorities of the four merits can then be calculated based on the priorities of strategic criteria and the defuzzified weights of the four merits. The results are shown in Table 3. The normalized priorities of the four merits are listed in the last column of Table 3: benefits $(b), 0.295$; opportunities $(o)$, 0.216 ; costs $(c), 0.266$; and risks $(r), 0.223$.

Based on the opinions of the experts collected from the questionnaire, we can further calculate the priorities of the criteria with respect to each merit, the interrelationship among the criteria under each merit, and the expected relative performance of the technologies under each criterion. That is, the collected data are synthesized into aggregated pairwise comparison matrices using the geometric average method first, and the Yager [36] ranking method is adopted next 


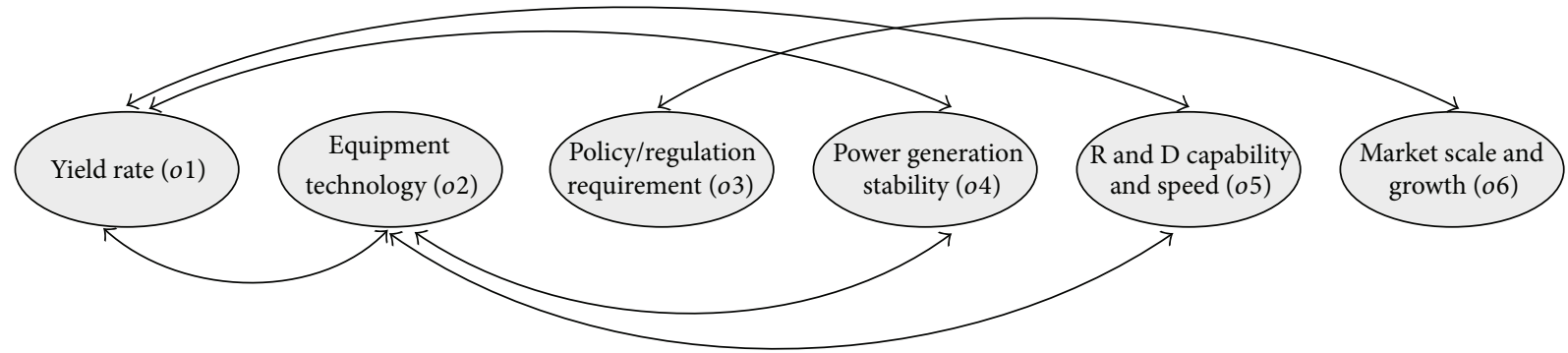

FIGURE 8: Subnetwork for the criteria under the opportunities merit.

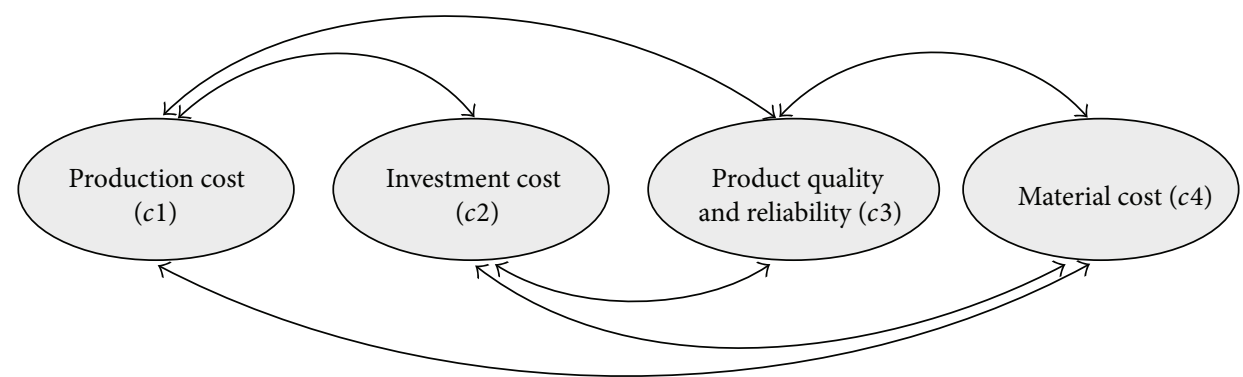

FIGURE 9: Subnetwork for the criteria under the costs merit.

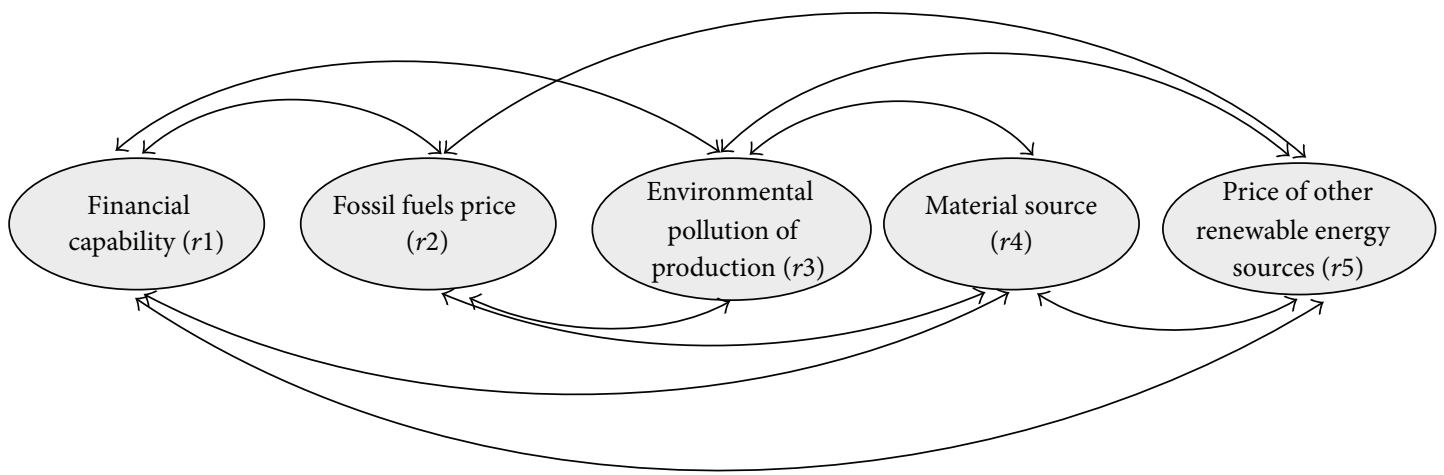

FIgURE 10: Subnetwork for the criteria under the risks merit.

TABLE 2: Integrated fuzzy weights of the merits on strategic criteria.

\begin{tabular}{lcccc}
\hline & Manufacturing capability $(S 1)$ & Market demand $(S 2)$ & Financial performance $(S 3)$ & Social responsibility $(S 4)$ \\
\hline Benefits & $(0.715,0.828,0.865,0.883)$ & $(0.684,0.795,0.831,0.865)$ & $(0.682,0.761,0.0832,0.866)$ & $(0.704,0.805,0.0854,0.877)$ \\
Opportunities & $(0.625,0.733,0.766,0.831)$ & $(0.382,0.481,0.526,0.621)$ & $(0.278,0.402,0.408,0.530)$ & $(0.526,0.609,0.676,0.755)$ \\
Costs & $(0.695,0.817,0.842,0.871)$ & $(0.535,0.654,0.684,0.759)$ & $(0.595,0.701,0.744,0.805)$ & $(0.673,0.773,0.820,0.860)$ \\
Risks & $(0.392,0.521,0.536,0.636)$ & $(0.627,0.716,0.777,0.822)$ & $(0.828,0.865,0.883,0.763)$ & $(0.300,0.425,0.432,0.555)$ \\
\hline
\end{tabular}

TABle 3: Priorities of the merits $(b, o, c, r)$.

\begin{tabular}{lcccccc}
\hline & $S 1$ & $S 2$ & $S 3$ & $S 4$ & Overall priorities & Normalized priorities \\
& $(0.381)$ & $(0.358)$ & $(0.165)$ & $(0.096)$ & 0.805 & 0.295 \\
Benefits & 0.823 & 0.794 & 0.785 & 0.81 & 0.590 & 0.216 \\
Opportunities & 0.739 & 0.502 & 0.405 & 0.642 & 0.727 & 0.266 \\
Costs & 0.806 & 0.658 & 0.663 & 0.782 & 0.610 & 0.223 \\
Risks & 0.520 & 0.735 & 0.65 & 0.428 & & \\
\hline
\end{tabular}


TABLE 4: Unweighted supermatrix for the benefits merit.

\begin{tabular}{ccccccccccc}
\hline & $\mathrm{G}$ & $b 1$ & $b 2$ & $b 3$ & $b 4$ & $A 1$ & $A 2$ & $A 3$ & $A 4$ & $A 5$ \\
\hline $\mathrm{G}$ & 1 & 0 & 0 & 0 & 0 & 0 & 0 & 0 & 0 & 0 \\
\hline$b 1$ & 0.179 & 0.634 & 0.347 & 0.161 & 0.186 & 0 & 0 & 0 & 0 & 0 \\
$b 2$ & 0.218 & 0.366 & 0.653 & 0.173 & 0.213 & 0 & 0 & 0 & 0 & 0 \\
$b 3$ & 0.274 & 0 & 0 & 0.367 & 0.274 & 0 & 0 & 0 & 0 & 0 \\
$b 4$ & 0.329 & 0 & 0 & 0.299 & 0.327 & 0 & 0 & 0 & 0 & 0 \\
\hline$A 1$ & 0 & 0.252 & 0.252 & 0.286 & 0.301 & 1 & 0 & 0 & 0 & 0 \\
$A 2$ & 0 & 0.231 & 0.231 & 0.294 & 0.277 & 0 & 1 & 0 & 0 & 0 \\
$A 3$ & 0 & 0.205 & 0.205 & 0.190 & 0.172 & 0 & 0 & 1 & 0 & 0 \\
$A 4$ & 0 & 0.201 & 0.201 & 0.148 & 0.156 & 0 & 0 & 0 & 1 & 0 \\
$A 5$ & 0 & 0.111 & 0.111 & 0.082 & 0.094 & 0 & 0 & 0 & 0 & 1 \\
\hline
\end{tabular}

TABLE 5: Weighted supermatrix for the benefits merit.

\begin{tabular}{ccccccccccc}
\hline & $\mathrm{G}$ & $b 1$ & $b 2$ & $b 3$ & $b 4$ & $A 1$ & $A 2$ & $A 3$ & $A 4$ & $A 5$ \\
\hline $\mathrm{G}$ & 0.5 & 0 & 0 & 0 & 0 & 0 & 0 & 0 & 0 & 0 \\
\hline$b 1$ & 0.089 & 0.317 & 0.173 & 0.081 & 0.093 & 0 & 0 & 0 & 0 & 0 \\
$b 2$ & 0.109 & 0.183 & 0.327 & 0.086 & 0.107 & 0 & 0 & 0 & 0 & 0 \\
$b 3$ & 0.137 & 0 & 0 & 0.183 & 0.137 & 0 & 0 & 0 & 0 & 0 \\
$b 4$ & 0.165 & 0 & 0 & 0.150 & 0.163 & 0 & 0 & 0 & 0 & 0 \\
\hline$A 1$ & 0 & 0.126 & 0.126 & 0.143 & 0.151 & 1 & 0 & 0 & 0 & 0 \\
$A 2$ & 0 & 0.115 & 0.115 & 0.147 & 0.138 & 0 & 1 & 0 & 0 & 0 \\
$A 3$ & 0 & 0.103 & 0.103 & 0.095 & 0.086 & 0 & 0 & 1 & 0 & 0 \\
$A 4$ & 0 & 0.101 & 0.101 & 0.074 & 0.078 & 0 & 0 & 0 & 1 & 0 \\
$A 5$ & 0 & 0.056 & 0.056 & 0.041 & 0.047 & 0 & 0 & 0 & 0 & 1 \\
\hline
\end{tabular}

TABLE 6: Limit supermatrix for the benefits merit.

\begin{tabular}{ccccccccccc}
\hline & $\mathrm{G}$ & $b 1$ & $b 2$ & $b 3$ & $b 4$ & $A 1$ & $A 2$ & $A 3$ & $A 4$ & $A 5$ \\
\hline $\mathrm{G}$ & 0 & 0 & 0 & 0 & 0 & 0 & 0 & 0 & 0 & 0 \\
\hline$b 1$ & 0 & 0 & 0 & 0 & 0 & 0 & 0 & 0 & 0 & 0 \\
$b 2$ & 0 & 0 & 0 & 0 & 0 & 0 & 0 & 0 & 0 & 0 \\
$b 3$ & 0 & 0 & 0 & 0 & 0 & 0 & 0 & 0 & 0 & 0 \\
$b 4$ & 0 & 0 & 0 & 0 & 0 & 0 & 0 & 0 & 0 & 0 \\
\hline$A 1$ & 0.243 & 0.232 & 0.179 & 0.267 & 0.272 & 1 & 0 & 0 & 0 & 0 \\
$A 2$ & 0.256 & 0.232 & 0.233 & 0.277 & 0.266 & 0 & 1 & 0 & 0 & 0 \\
$A 3$ & 0.199 & 0.208 & 0.217 & 0.194 & 0.185 & 0 & 0 & 1 & 0 & 0 \\
$A 4$ & 0.184 & 0.205 & 0.214 & 0.165 & 0.170 & 0 & 0 & 0 & 1 & 0 \\
$A 5$ & 0.118 & 0.123 & 0.157 & 0.098 & 0.106 & 0 & 0 & 0 & 0 & 1 \\
\hline
\end{tabular}

to calculate defuzzified comparison matrices. Based on the defuzzified aggregated comparison matrices, we can calculate the priority vectors. Then, the priority vectors are entered into the designated places in an unweighted supermatrix. The unweighted supermatrix for the benefits merit is as shown in Table 4. A weighted supermatrix is formed to make the matrix stochastic, as shown in Table 5. By taking the weighted supermatrix to a large power, a limit supermatrix is calculated, as shown in Table 6 . The $(3,1)$ block of the limit supermatrix shows the priorities of the solar cell technology alternatives. Under the benefits merit, the priorities for $A 1$,
$A 2, A 3, A 4$, and $A 5$ are $0.243,0.256,0.199,0.184$, and 0.118 , respectively.

The relative performances of solar cell technology alternatives under each merit are shown in Table 7. Under the benefits merit, crystalline silicon cell $(A 2)$ performs the best with a priority of 0.256 , followed by dye sensitized solar cell $(A 1)$ with 0.243 and concentrating cell (GaAs) (A3) with 0.199 . Under the opportunities merit, dye sensitized solar cell (DSSC) (A1) performs the best with a priority of 0.236 , followed by organic cell $(A 5)$ with 0.199 . Under the costs merit, concentrating cell (GaAs) $(A 3)$ is the least costly with a normalized reciprocal priority of 0.242 , followed by crystalline silicon cell (A2) with 0.226 . Under the risks merit, the least risky alternative is crystalline silicon cell $(A 2)$ with a normalized reciprocal priority of 0.317 , followed by thin film cell (A4) with 0.183 and concentrating cell (GaAs) $(A 3)$ with 0.182 . The results show that crystalline silicon cell (A2) ranks the first under the benefits and risks merits, dye sensitized solar cell (DSSC) (A1) ranks the first under the opportunities merit, and concentrating cell (GaAs) (A3) ranks the first under the costs merit. Because the performances of the alternatives under each merit are different, the final ranking of the five alternatives is not clear.

By aggregating the scores of each alternative under $B, O$, $C$, and $R$, the final ranking of the alternatives can be calculated. There are five methods for accomplishing the task, that is, additive, probabilistic additive, subtractive, multiplicative priority powers, and multiplicative. Table 8 shows the results. The priority of dye sensitized solar cell (DSSC) (A1) using each of the five methods is calculated as follows.

Additive. Consider

$$
\begin{aligned}
& 0.295 * 0.243+0.216 * 0.236+0.266 * 0.221 \\
& +0.223 * 0.159=0.2171
\end{aligned}
$$

Probabilistic Additive. Consider

$$
\begin{array}{rl}
0.295 & * 0.243+0.216 * 0.236+0.266 \\
& *(1-0.173)+0.223 *(1-0.235)=0.5133 .
\end{array}
$$

Subtractive. Consider

$$
\begin{array}{rl}
0.295 & * 0.243+0.216 * 0.236-0.266 * 0.173 \\
& -0.223 * 0.235=0.0240
\end{array}
$$

Multiplicative Priority Powers. Consider

$$
0.243^{0.295} * 0.236^{0.216} * 0.221^{0.266} * 0.159^{0.223}=0.2144 \text {. }
$$

Multiplicative. Consider

$$
\frac{0.243 * 0.236}{(0.173 * 0.235)}=1.4070
$$

No matter which aggregation method is used, crystalline silicon cell ( $A 2)$ always ranks the first, dye sensitized solar cell 
TABLE 7: Performance of alternatives under the four merits.

\begin{tabular}{|c|c|c|c|c|c|c|c|c|}
\hline Merits & Benefits & Opportunities & & Costs & & & Risks & \\
\hline Priorities & 0.295 & 0.216 & & 0.266 & & & 0.223 & \\
\hline Alternatives & Normalized & Normalized & Normalized & Reciprocal & $\begin{array}{c}\text { Normalized } \\
\text { Reciprocal }\end{array}$ & Normalized & Reciprocal & $\begin{array}{l}\text { Normalized } \\
\text { Reciprocal }\end{array}$ \\
\hline $\begin{array}{l}\text { Dye sensitized solar cell } \\
\text { (DSSC) }(A 1)\end{array}$ & 0.243 & 0.236 & 0.173 & 5.773 & 0.221 & 0.235 & 4.250 & 0.159 \\
\hline Crystalline silicon cell $(A 2)$ & 0.256 & 0.193 & 0.169 & 5.902 & 0.226 & 0.118 & 8.447 & 0.317 \\
\hline $\begin{array}{l}\text { Concentrating cell }(\mathrm{GaAs}) \\
(A 3)\end{array}$ & 0.199 & 0.180 & 0.159 & 6.304 & 0.242 & 0.206 & 4.843 & 0.182 \\
\hline Thin film cell $(A 4)$ & 0.184 & 0.193 & 0.226 & 4.420 & 0.170 & 0.205 & 4.881 & 0.183 \\
\hline Organic cell $(A 5)$ & 0.118 & 0.199 & 0.273 & 3.670 & 0.141 & 0.235 & 4.256 & 0.160 \\
\hline
\end{tabular}

TABLE 8: Final priorities of alternatives.

\begin{tabular}{|c|c|c|c|c|c|c|c|c|c|c|}
\hline \multirow{2}{*}{$\begin{array}{l}\text { Methods } \\
\text { Alternatives } \\
\end{array}$} & \multicolumn{2}{|c|}{ Additive } & \multicolumn{2}{|c|}{ Probabilistic additive } & \multicolumn{2}{|c|}{ Subtractive } & \multicolumn{2}{|c|}{ Multiplicative priority powers } & \multicolumn{2}{|c|}{ Multiplicative } \\
\hline & Priorities & Ranking & Priorities & Ranking & Priorities & Ranking & Priorities & Ranking & Priorities & Ranking \\
\hline $\begin{array}{l}\text { Dye sensitized solar } \\
\text { cell (DSSC) }(A 1)\end{array}$ & 0.2171 & 2 & 0.5133 & 2 & 0.0240 & 2 & 0.2144 & 2 & 1.4070 & 2 \\
\hline $\begin{array}{l}\text { Crystalline silicon cell } \\
(A 2)\end{array}$ & 0.2479 & 1 & 0.5348 & 1 & 0.0455 & 1 & 0.2443 & 1 & 2.4583 & 1 \\
\hline $\begin{array}{l}\text { Concentrating cell } \\
(\mathrm{GaAs})(A 3)\end{array}$ & 0.2023 & 3 & 0.4985 & 3 & 0.0091 & 3 & 0.2009 & 3 & 1.0921 & 3 \\
\hline Thin film cell $(A 4)$ & 0.1819 & 4 & 0.4794 & 4 & -0.0100 & 4 & 0.1817 & 4 & 0.7666 & 4 \\
\hline Organic cell $(A 5)$ & 0.1507 & 5 & 0.4421 & 5 & -0.0473 & 5 & 0.1480 & 5 & 0.3661 & 5 \\
\hline
\end{tabular}

TABLE 9: Importance of criteria.

\begin{tabular}{|c|c|c|c|c|}
\hline Merits & Criteria & Criterion priorities & $\begin{array}{l}\text { Integrated priorities } \\
\text { in the network }\end{array}$ & Integrated ranking \\
\hline \multirow{4}{*}{$\begin{array}{l}\text { Benefits } \\
(0.295)\end{array}$} & (b1) Mass production technology & 0.179 & 0.0528 & 8 \\
\hline & (b2) Delivery-on-time rate & 0.218 & 0.0643 & 6 \\
\hline & (b3) Material usage reduction & 0.274 & 0.0808 & 3 \\
\hline & (b4) Conversion efficiency & 0.329 & 0.0971 & 1 \\
\hline \multirow{6}{*}{$\begin{array}{l}\text { Opportunities } \\
(0.216)\end{array}$} & (o1) Yield rate & 0.127 & 0.0274 & 16 \\
\hline & (o2) Equipment technology & 0.125 & 0.0270 & 17 \\
\hline & (o3) Policy/regulation requirement & 0.112 & 0.0242 & 18 \\
\hline & (o4) Power generation stability & 0.214 & 0.0462 & 13 \\
\hline & (o5) R and D capability and speed & 0.225 & 0.0486 & 10 \\
\hline & (o6) Market scale and growth & 0.197 & 0.0426 & 14 \\
\hline \multirow{4}{*}{$\begin{array}{l}\text { Costs } \\
(0.266)\end{array}$} & (c1) Production cost & 0.141 & 0.0375 & 15 \\
\hline & (c2) Investment cost & 0.242 & 0.0644 & 5 \\
\hline & (c3) Product quality and reliability & 0.328 & 0.0872 & 2 \\
\hline & (c4) Material cost & 0.290 & 0.0771 & 4 \\
\hline \multirow{5}{*}{$\begin{array}{l}\text { Risks } \\
(0.223)\end{array}$} & ( $r 1)$ Financial capability & 0.086 & 0.0192 & 19 \\
\hline & $(r 2)$ Fossil fuels price & 0.270 & 0.0602 & 7 \\
\hline & (r3) Environmental pollution of production & 0.211 & 0.0471 & 12 \\
\hline & (r4) Material source & 0.222 & 0.0495 & 9 \\
\hline & $(r 5)$ Price of other renewable energy sources & 0.212 & 0.0473 & 11 \\
\hline
\end{tabular}




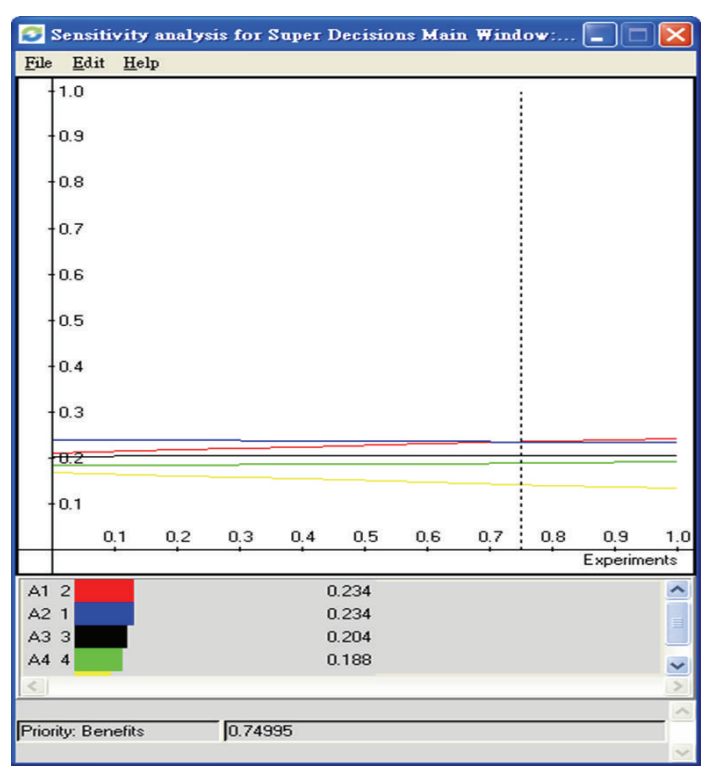

(1) Changes in the priority of benefits

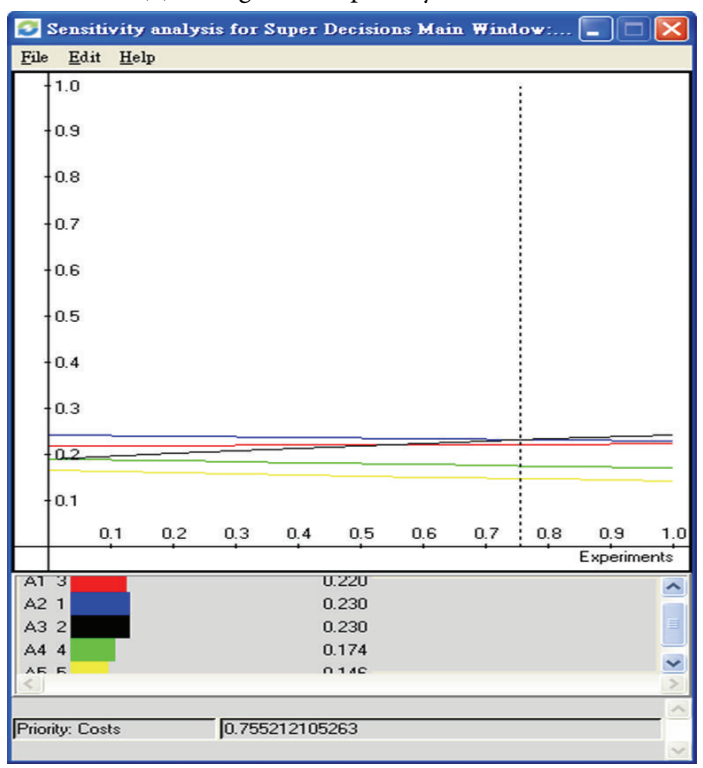

(3) Changes in the priority of costs

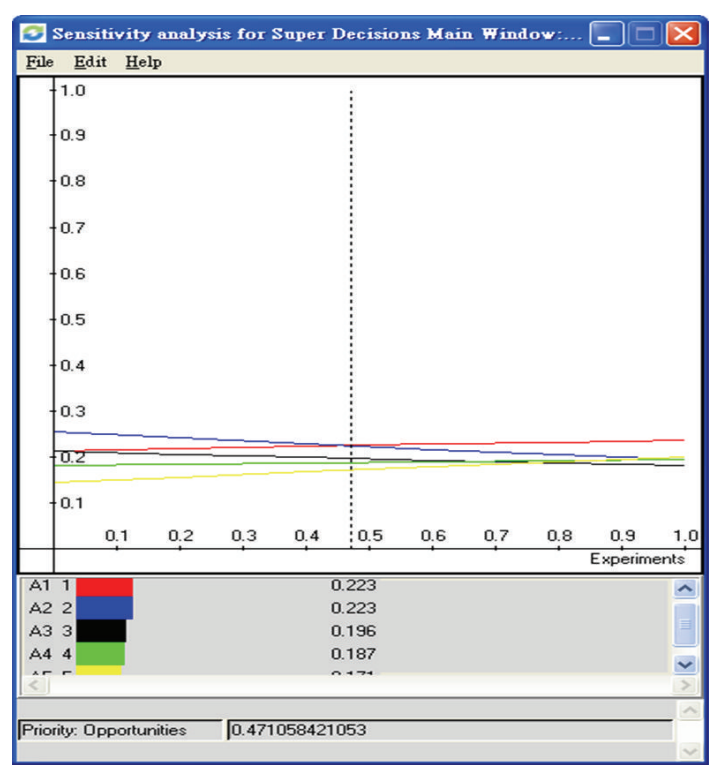

(2) Changes in the priority of opportunities

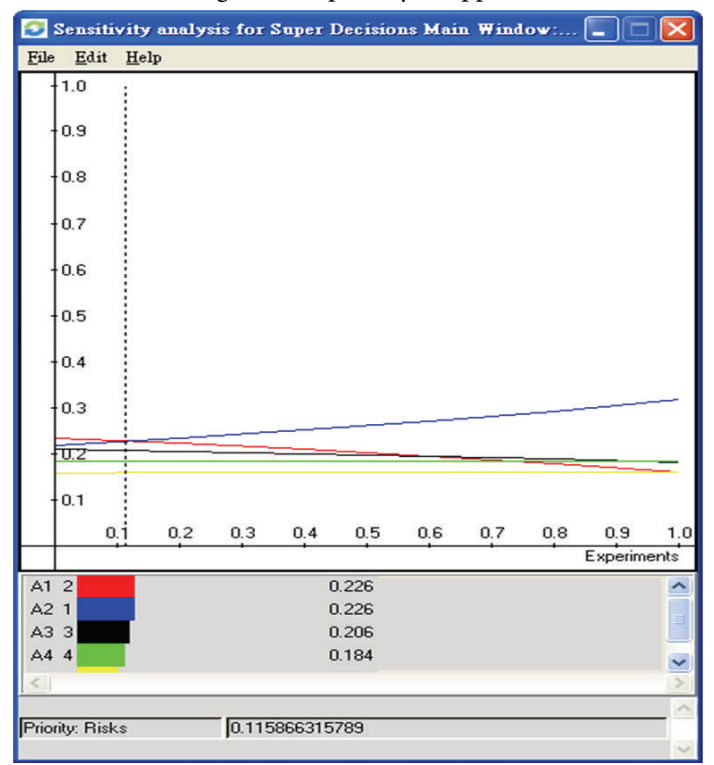

(4) Changes in the priority of risks

FIGURE 11: Sensitivity analysis when applying the additive method.

(DSSC) (A1) the second, and concentrating cell (GaAs) $(A 3)$ the third.

A sensitivity analysis is performed next to examine the robustness of the outcomes. The software Super Decisions [36] is applied to fulfill the task. The priorities of the merits are changed to observe whether the ranking of alternatives changes. Figures 11(1), 11(2), 11(3), and 11(4) show the sensitivity analysis graphs under the additive method when the priority of benefits, opportunities, costs, and risks changes, respectively. The best technology may change when the priorities of the merits change. For example, the original priority of benefits $(b)$ is 0.295 , and the best alternative overall is $A 2$. However, when $b$ increases from 0.295 to 0.750 , the best alternative shifts from $A 2$ to $A 1$. The original priority of opportunities $(o)$ is 0.216 . When $o$ increases from 0.216 to 0.471 , the best alternative changes from $A 2$ to $A 1$. The original priority of costs $(c)$ is 0.266 . When $c$ increases from 0.266 to 0.755 , the best alternative shifts from $A 2$ to $A 3$. The original priority of risks $(r)$ is 0.223 . When $r$ decreases from 0.223 to 0.116 , the best alternative changes from $A 2$ to $A 1$. Since it is unlikely that the priorities of the four merits will have such big changes, the current solution is rather robust.

The management needs to understand the importance of the criteria when making the solar cell technology selection decision, and such information can be obtained from the calculation results. The importance of the criteria under each of the four merits is shown in Table 9. The most important criterion under the benefits merit is conversion efficiency (b4), 
TABLE 10: Performance of alternatives with respect to each criterion.

\begin{tabular}{|c|c|c|c|c|c|}
\hline \multirow{2}{*}{ Criteria } & \multicolumn{5}{|c|}{ Alternatives } \\
\hline & $A 1$ & $A 2$ & $A 3$ & $A 4$ & $A 5$ \\
\hline (b1) Mass production technology & 0.232 & 0.232 & 0.208 & 0.205 & 0.123 \\
\hline (b2) Delivery-on-time rate & 0.179 & 0.233 & 0.217 & 0.214 & 0.157 \\
\hline (b3) Material usage reduction & 0.267 & 0.277 & 0.194 & 0.165 & 0.098 \\
\hline (b4) Conversion efficiency & 0.272 & 0.266 & 0.185 & 0.170 & 0.106 \\
\hline (o1) Yield rate & 0.318 & 0.153 & 0.169 & 0.179 & 0.183 \\
\hline (o2) Equipment technology & 0.324 & 0.148 & 0.155 & 0.179 & 0.194 \\
\hline (o3) Policy/regulation requirement & 0.302 & 0.153 & 0.171 & 0.190 & 0.184 \\
\hline (o4) Power generation stability & 0.177 & 0.218 & 0.200 & 0.200 & 0.206 \\
\hline (o5) R and D capability and speed & 0.192 & 0.220 & 0.182 & 0.198 & 0.208 \\
\hline (o6) Market scale and growth & 0.203 & 0.212 & 0.184 & 0.199 & 0.202 \\
\hline (c1) Production cost & 0.159 & 0.221 & 0.140 & 0.229 & 0.251 \\
\hline (c2) Investment cost & 0.151 & 0.169 & 0.136 & 0.244 & 0.301 \\
\hline (c3) Product quality and reliability & 0.205 & 0.144 & 0.192 & 0.218 & 0.242 \\
\hline (c4) Material cost & 0.163 & 0.174 & 0.150 & 0.220 & 0.294 \\
\hline ( $r 1)$ Financial capability & 0.244 & 0.114 & 0.213 & 0.204 & 0.225 \\
\hline$(r 2)$ Fossil fuels price & 0.239 & 0.107 & 0.223 & 0.206 & 0.225 \\
\hline (r3) Environmental pollution of production & 0.244 & 0.128 & 0.192 & 0.212 & 0.225 \\
\hline$(r 4)$ Material source & 0.224 & 0.133 & 0.172 & 0.198 & 0.272 \\
\hline
\end{tabular}

with a priority of 0.329 . This indicates that the major benefit considered when selecting a technology is the efficiency for conversing solar power to electricity. The second and third criteria are material usage reduction (b3) (0.274) and deliveryon-time rate (b2) (0.218). Under the opportunities merit, $R$ and $D$ capability and speed (o5) (0.225) is the most important criterion, and power generation stability (o4) (0.214) ranks the second. Under the costs merit, product quality and reliability (c3) (0.328) is the major concern, followed by material cost (c4) (0.290). Under the risks merit, fossil fuels price $(r 2)$ $(0.270)$ is what the firm concerns the most since it may affect the demand of renewable energy. Material source $(r 4)(0.222)$ ranks the second. The integrated priorities of criteria and their respective rankings are also shown in Table 9. Among all the criteria, conversion efficiency (b4), with an integrated priority of 0.0971 in the network, is the most important concern in selecting a technology. Other important criteria include product quality and reliability (c3), material usage reduction (b3), material cost (c4), and investment cost (c2).

In the case study, the expected performance of alternatives with respect to each criterion can be learned. The performance results are found in the $(3,2)$ block of the limit supermatrix. For instance, the relative performances of $A 1$ to $A 5$ under mass production technology (b1) are shown in the first column of the $(3,2)$ block of the limit supermatrix for the benefits merit in Table 6, and they are 0.232, 0.232, $0.208,0.205$, and 0.123 , respectively. The performances of the alternatives under various criteria are shown in Table 10. The best performance of an alternative under each criterion is shown in bold. Under mass production technology $(b 1)$, both $A 1$ and $A 2$ perform the best. $A 1$ performs the best under 8 criteria. $A 2, A 4$, and $A 5$ perform the best under 6,2 , and 2 criteria, respectively. Even though $A 1$ performs the best in more criteria than $A 2$ does, crystalline silicone cell ( $A 2)$, with the consideration of different criterion importance weights, has the most outstanding performance ovserall.

In conclusion, the criteria of solar technology can be logically identified, organized, reviewed, and concluded by this model to avoid the rank bias and halo effect [39] in group discussion. In addition, the quality of final decision can be more consistent through this systematic process.

\section{Conclusions}

With natural resource scarcity and environmental protection, renewable energy sources have been recognized as the last resort for future economic development, and solar energy is one of the most promising renewable energy sources from the perspective of environmental sustainability. However, the PV market is facing a rather volatile market cycle in response to the global economic condition. A PV firm must have a solid foundation in its technology in order to survive and to lead the market in the future. Therefore, good evaluation and selection of the most appropriate technology become a complicated decision that a firm often encounters.

This research constructed an integrated model, which incorporates interpretive structural modeling (ISM), benefits, opportunities, costs, and risks concept (BOCR), and fuzzy analytic network process (FANP), for facilitating the evaluation of technologies. The model consists of three phases. In the first phase, a control hierarchy and a BOCR-ANP network are constructed. In the second phase, the relevant priority weights in the control hierarchy and the BOCR-ANP network are calculated. In the last phase, the technology alternatives 
are ranked. The proposed model is implemented in a solar cell firm to help select the most suitable solar cell technologies.

This evaluation model is constructed under known technology of solar cell for technology selection for mass production. By applying the proposed model, experts can understand the expected performance of technology alternatives based on different criteria and merits. The overall ranking of the technologies can be calculated as a result. Further studies can be conducted for the conceptualized or developing stage of solar cell technology to facilitate decision making on new technology development to ensure the success of new product introduction. In addition, based on the special needs of a firm, the proposed model can be adjusted as required by the firm in the PV industry or in another industry to help select the most suitable technology.

\section{Conflict of Interests}

The authors declare that there is no conflict of interests regarding the publication of this paper.

\section{References}

[1] T. Tsoutsos, N. Frantzeskaki, and V. Gekas, "Environmental impacts from the solar energy technologies," Energy Policy, vol. 33, no. 3, pp. 289-296, 2005.

[2] T. M. Pavlovic, D. D. Milosavljevic, D. Mirjanic, L. S. Pantic, I. S. Radonjic, and D. Pirsl, "Assessments and perspectives of PV solar power engineering in the Republic of Srpska (Bosnia and Herzegovina)," Renewable and Sustainable Energy Reviews, vol. 18, pp. 119-133, 2013.

[3] A. H. I. Lee, H. H. Chen, and H.-Y. Kang, "A model to analyze strategic products for photovoltaic silicon thin-film solar cell power industry," Renewable and Sustainable Energy Reviews, vol. 15, no. 2, pp. 1271-1283, 2011.

[4] European Photovoltaic Industry Association, "Global market outlook for photovoltaics, 2013-2017,” 2014, http://www.epia .org/fileadmin/user_upload/Publications/GMO_2013_-_Final_ PDF.pdf.

[5] W. Hoffmann, "PV solar electricity industry: market growth and perspective," Solar Energy Materials and Solar Cells, vol. 90, no. 18-19, pp. 3285-3311, 2006.

[6] R. M. Swanson, "Photovoltaics power up," Science, vol. 324, no. 5929, pp. 891-892, 2009.

[7] M. A. Green, K. Emery, Y. Hishikawa, W. Warta, and E. D. Dunlop, "Solar cell efficiency tables (version 39)," Progress in Photovoltaics: Research and Applications, vol. 20, no. 1, pp. 1220, 2012.

[8] Wikipedia, “Solar cell," 2014, http://en.wikipedia.org/wiki/ Solar_cell.

[9] Applied Materials, “Thin films solar cells," 2008, http://www .appliedmaterials.com/products/thin_films_solar_cells_5.html.

[10] Applied Materials, "Photovoltaic technology: now and for the future," 2008, http://www.appliedmaterials.com/.

[11] W. A. Wang, "Analysis of production plan for silicone solar cell industry: a special report," Photonics Industry and Technology Report, vol. 75, pp. 44-48, 2008 (Chinese).

[12] University of New South Wales (UNSW), "Future students: what are photovoltaic devices," 2008, http://www.pv.unsw.edu .au/future-students/pv-devices/thin-film.asp.
[13] M. Despeisse, C. Ballifa, A. Feltrina et al., "Research and developments in thin-film silicon photovoltaics," in Thin Film Solar Technology, A. E. Delahoy and L. A. Eldada, Eds., vol. 7409 of Proceedings of SPIE, 2009.

[14] S. E. Chen, "Strategic analysis of PV glass: a special report," Photonics Industry and Technology Report, vol. 75, pp. 44-48, 2008.

[15] A. H. I. Lee, H.-Y. Kang, and C.-C. Chang, "An integrated interpretive structural modeling-fuzzy analytic network processbenefits, opportunities, costs and risks model for selecting technologies," International Journal of Information Technology and Decision Making, vol. 10, no. 5, pp. 843-871, 2011.

[16] F. T. S. Chan, M. H. Chan, and N. K. H. Tang, "Evaluation methodologies for technology selection," Journal of Materials Processing Technology, vol. 107, no. 1-3, pp. 330-337, 2000.

[17] S. W. Hung and S. C. Tseng, "A new framework integrating environmental effects into technology evaluation," Journal of Business Ethics, vol. 95, no. 4, pp. 543-556, 2010.

[18] M. Punniyamoorthy and P. V. Ragavan, "A strategic decision model for the justification of technology," International Journal of Advanced Manufacturing Technology, vol. 21, no. 1, pp. 72-78, 2003.

[19] Y. L. Hsu, C. H. Lee, and V. B. Kreng, "The application of fuzzy delphi method and fuzzy AHP in lubricant regenerative technology selection," Expert Systems with Applications, vol. 37, no. 1, pp. 419-425, 2010.

[20] H.-Y. Kang, A. H. I. Lee, C.-C. Chang, and M.-S. Kang, "A model for selecting technologies in new product development," Mathematical Problems in Engineering, vol. 2012, Article ID 358129, 17 pages, 2012.

[21] R. Alamian, R. Shafaghat, S. J. Miri, N. Yazdanshenas, and M. Shakeri, "Evaluation of technologies for harvesting wave energy in Caspian Sea," Renewable and Sustainable Energy Reviews, vol. 32, pp. 468-476, 2014.

[22] C. Bassano, P. Deiana, and G. Girardi, "Modeling and economic evaluation of the integration of carbon capture and storage technologies into coal to liquids plants," Fuel, vol. 116, pp. 850860, 2014.

[23] Y. P. Lee, A strategic analysis of Taiwan's solar cell industry [Dissertation], National Chiao Tung University, 2005 (Chinese).

[24] C. Y. Lai, Localized core competencies of the photovoltaic industry in Taiwan [Dissertation], National Chiao Tung University, 2006 (Chinese).

[25] C. D. Yue and S. S. Wang, "GIS-based evaluation of multifarious local renewable energy sources: a case study of the Chigu area of southwestern Taiwan," Energy Policy, vol. 34, no. 6, pp. 730-742, 2006.

[26] F. Chen, S. M. Lu, and Y. L. Chang, "Renewable energy in Taiwan: its developing status and strategy," Energy, vol. 32, no. 9, pp. 1634-1646, 2007.

[27] Y. H. Ting, The opportunities of major players in Taiwanese solar energy industry [Dissertation], National Chiao Tung University, 2008 (Chinese).

[28] K. H. Chen, Industry development analysis for Taiwan thin film solar cell [Dissertation], National Chiao Tung University, 2008 (Chinese).

[29] J. Welling, A strategic analysis of Taiwan's industry for solar cell process equipment [Dissertation], National Chiao Tung University, 2008 (Chinese).

[30] J. J. Hwang, "Promotional policy for renewable energy development in Taiwan," Renewable and Sustainable Energy Reviews, vol. 14, no. 3, pp. 1079-1087, 2010. 
[31] A. H. I. Lee, C.-Y. Lin, H.-Y. Kang, and W. H. Lee, "An integrated performance evaluation model for photovoltaics industry," Energies, vol. 5, no. 4, pp. 1271-1291, 2012.

[32] A. H. I. Lee, H.-Y. Kang, and C.-Y. Lin, "A performance evaluation model using FAHP/DEA and Malmquist productivity index to assess the photovoltaics industry in Taiwan," Journal of Testing and Evaluation, vol. 42, no. 1, pp. 211-228, 2014.

[33] T. L. Saaty, Decision Making with Dependence and Feedback: The Analytic Network Process, RWS Publications, Pittsburgh, Pa, USA, 1996.

[34] R. W. Saaty, Decision Making in Complex Environment: The Analytic Hierarchy Process (AHP) for Decision Making and the Analytic Network Process (ANP) for Decision Making with Dependence and Feedback, Super Decisions, Pittsburgh, Pa, USA, 2003.

[35] H.-Y. Kang, M.-C. Hung, W. L. Pearn, A. H. I. Lee, and M.-S. Kang, "An integrated multi-criteria decision making model for evaluating wind farm performance," Energies, vol. 4, no. 11, pp. 2002-2026, 2011.

[36] R. R. Yager, "A procedure for ordering fuzzy subsets of the unit interval," Information Sciences, vol. 24, no. 2, pp. 143-161, 1981.

[37] T. L. Saaty, The Analytic Hierarchy Process, McGraw-Hill, New York, NY, USA, 1980.

[38] A. H. I. Lee, H. H. Chen, and Y. Tong, "Developing new products in a network with efficiency and innovation," International Journal of Production Research, vol. 46, no. 17, pp. 4687-4707, 2008.

[39] R. E. Nisbett and T. D. Wilson, "The halo effect: evidence for unconscious alteration of judgments," Journal of Personality and Social Psychology, vol. 35, no. 4, pp. 250-256, 1977. 


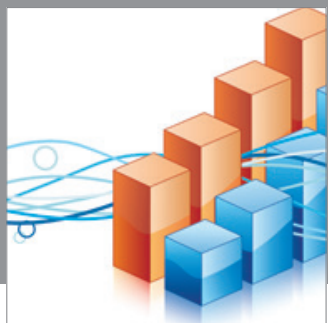

Advances in

Operations Research

mansans

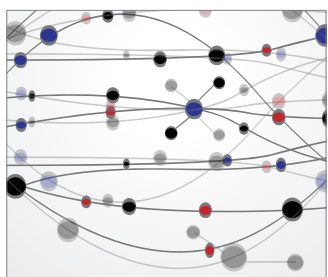

The Scientific World Journal
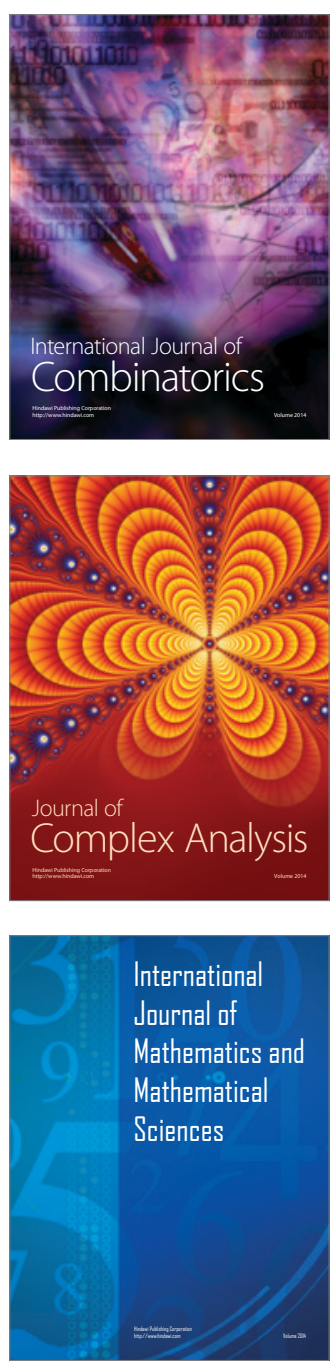
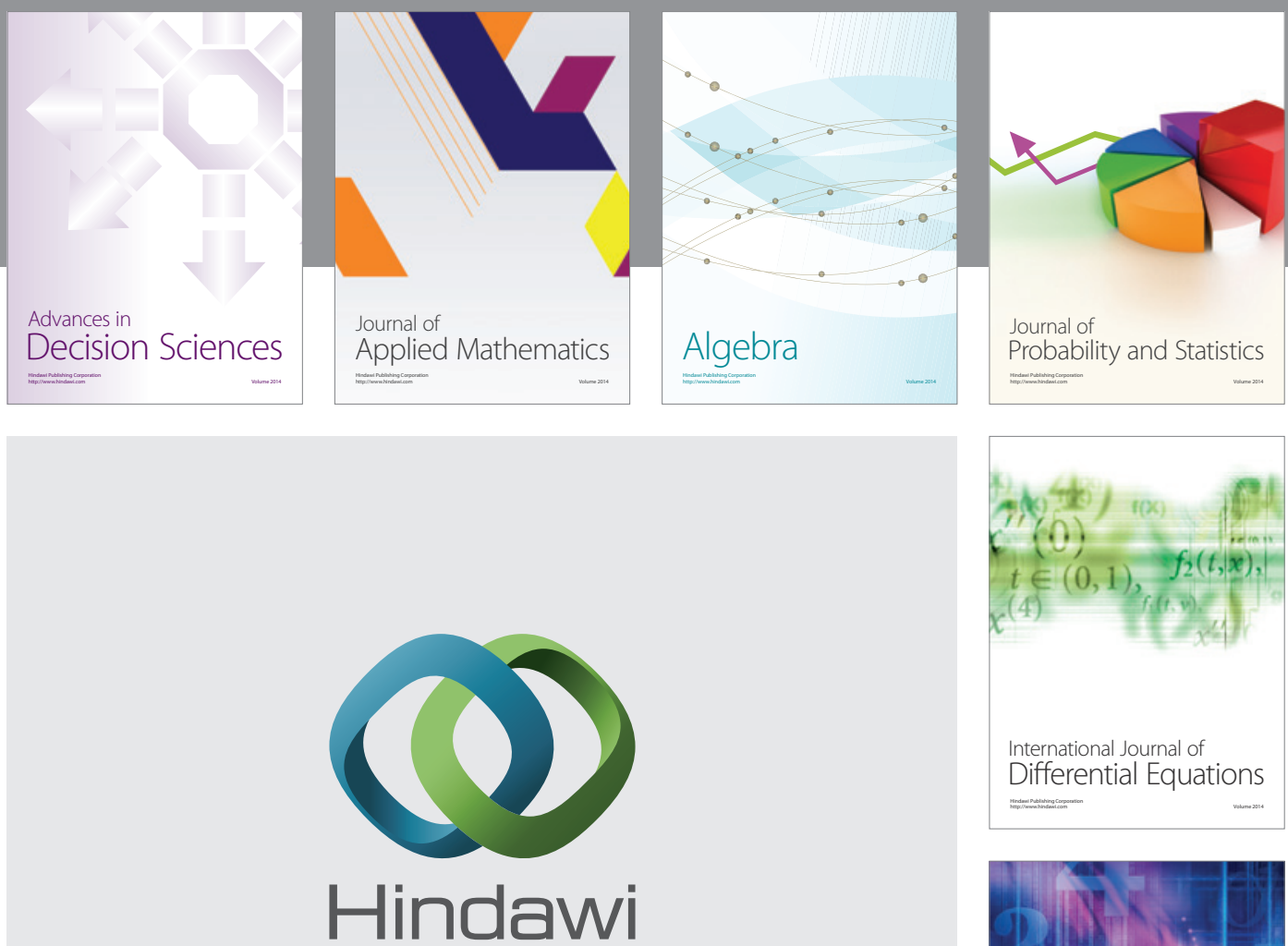

Submit your manuscripts at http://www.hindawi.com
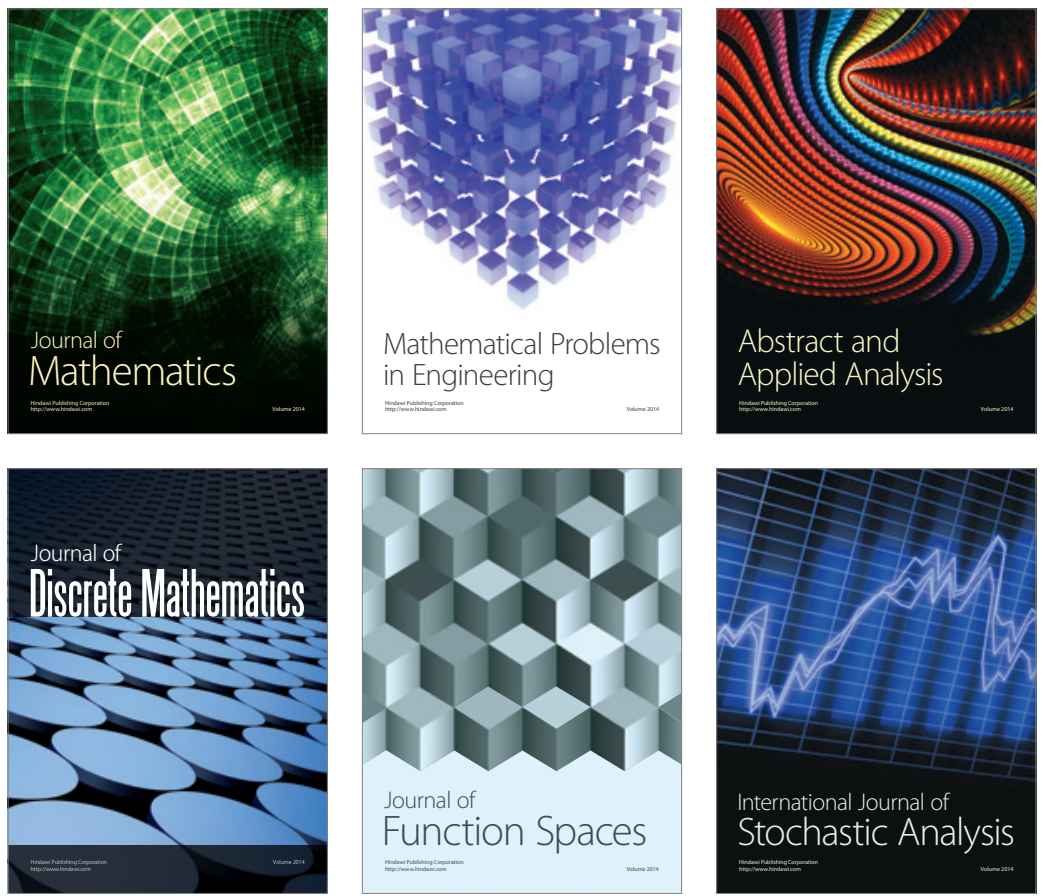

Journal of

Function Spaces

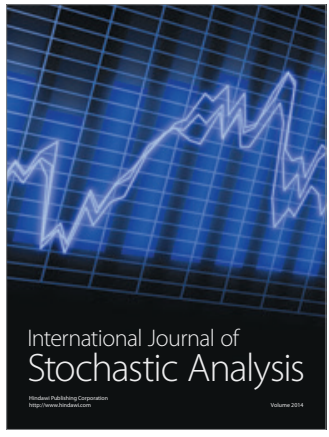

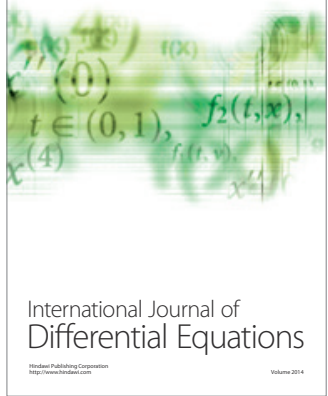
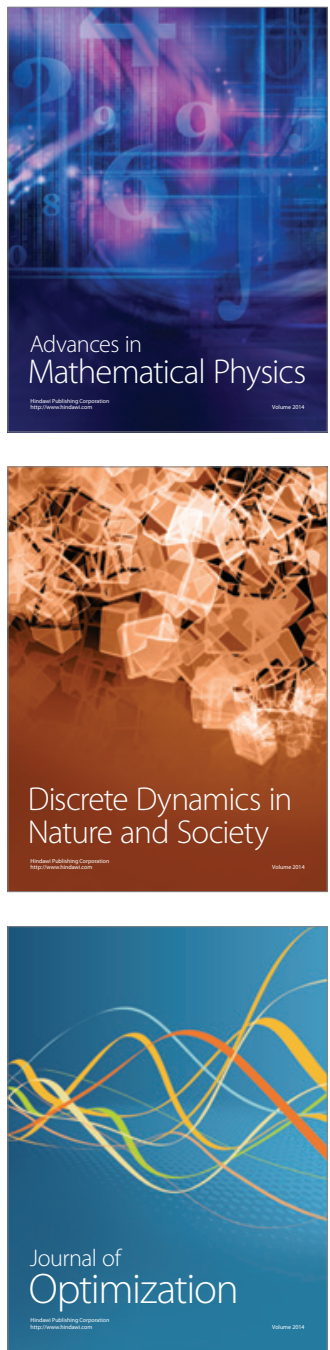